\title{
Antarctic demersal finfish around the Elephant and the South Orkney islands: distribution, abundance and biological characteristics
}

\author{
Patricio M. Arana ${ }^{1}$, Christopher D. Jones ${ }^{2}$, Nicolás A. Alegría ${ }^{3}$ \\ Roberto Sarralde ${ }^{4}$ \& Renzo Rolleri ${ }^{1}$ \\ ${ }^{1}$ Escuela de Ciencias del Mar, Pontificia Universidad Católica de Valparaíso \\ Valparaíso, Chile \\ ${ }^{2}$ Antarctic Ecosystem Research Division, NOAA Southwest Fisheries \\ Science Center, La Jolla, USA \\ ${ }^{3}$ Instituto de Investigación Pesquera, Talcahuano, Chile \\ ${ }^{4}$ Instituto Español de Oceanografía, Tenerife, España \\ Corresponding author: Patricio M. Arana (patricio.arana@ pucv.cl)
}

\begin{abstract}
A research survey for demersal finfish was completed using bottom trawl fishing gear, following a random stratified sampling design, between 50 and $500 \mathrm{~m}$ on shelf areas of Subarea 48.1 (Elephant Island) and Subarea 48.2 (South Orkney Island). An acoustic survey was simultaneously carried out to enhance knowledge of bathymetry and the distribution of fish and krill in the studied area. The cruise took place between the 6 and 27 January 2018. A total of 36 hauls were carried out, 15 around Elephant Island and 21 around the South Orkney Islands. A total of 37 fish species were caught with a total biomass of $19,112 \mathrm{~kg}$. The main species encountered included Notothenia rossii and Champsocephalus gunnari, with nominal catches weighing 16,204 $(85 \%)$ and $876 \mathrm{~kg}(5 \%)$, respectively. Other species of fish accounted noticeably for lower amounts $(11 \%)$, such as Gobionotothen gibberifrons $(330 \mathrm{~kg})$, Chaenocephalus aceratus $(322 \mathrm{~kg})$, and Pseudochaenichthys georgianus $(299 \mathrm{~kg})$. Indicative estimates of standing stock biomass suggested that in this cruise, $N$. rossii was the most abundant demersal finfish species in the Elephant Island area, followed by $C$. gunnari. Differently, on the South Orkney Islands shelf, the most abundant species was G. gibberifrons, followed by P. georgianus. The study provides biological data (length frequency distribution, median size, sex ratio, gonad maturity stages, length-weight relationship) on the main species captured during the survey, and the oceanographic characteristics (depth profiles of temperature, salinity, density) obtained with CTD around the South Orkney Islands.
\end{abstract}

Keywords: Antarctica; finfish; relative abundance; biological characteristics; acoustic; environment

\section{INTRODUCTION}

The marine flora and fauna that inhabit Antarctica, as well as their delicate ecological relationships, are of interest to many countries regarding research and promotion of their survival and conservation (Hempel, 2007; Griffiths, 2010; Murphy, 2014). However, the remote and hard-to-access nature of this region limit the knowledge of the mechanisms that underlie these marine ecosystems and, although expanding current knowledge is presented as a major objective for research activities, still requires further development to contribute adequately to the implementation of conservation measures (Constable et al., 2000). Thus, Antarctic living marine organisms are a valuable source of scientific interest and, at the same time, they represent a considerable challenge to achieve an appropriate management approach that will allow the commercial exploitation of some species (Constable $e t$ al., 2000; Fabra \& Gascón, 2008).

For many years the waters surrounding the Antarctic continent were subject to marine mammal exploitation, later giving way pursuing Antarctic fish and Antarctic krill (Euphausia superba) (Nicol \& 
Endo, 1997; Tin et al., 2009). Fishing activities, specifically in the Scotia Sea region of the Southern Ocean (Statistical subareas 48.1, 48.2 and 48.3), started almost half a century ago. Catches were carried out by USSR vessels targeting mainly Nototheniidae (Notothenia rossii) and Channichthyidae (Champsocephalus gunnari, Chaenocephalus aceratus and Chaenodraco wilsoni) (CCAMLR, 1990a,b). Due to the drastic decrease of these species, especially in subareas 48.1 and 48.2 (Kock, 1991), the Commission for the Conservation of the Antarctic Marine Living Resources (CCAMLR) imposed a moratorium on finfish fishing since the 1989/90 season. This Conservation Measure (CM 32-02) is still in force.

In recent decades, special attention has been given to monitoring the status and recovery of fish stocks on shelf areas of subareas 48.1 and 48.2. Until recently, these surveys recorded little increase in terms of fish biomass and abundance levels (e.g., Jones et al., 2003; Kock et al., 2007; Jones, 2009; Marschoff et al., 2012; CCAMLR, 2013a; Barrera-Oro et al., 2017). However, in the investigation carried out by Kock \& Jones (2012a) onboard the RV Polarstern in the South Shetland Islands during March-April 2012, N. rossii and $C$. gunnari showed a clear signal of recovery in contrast with a previous survey (Kock et al., 2007).

In the present study, we provide additional insight into the state of fish populations around Elephant Island (Subarea 48.1) and the South Orkney Islands (Subarea 48.2) from a bottom trawl research survey suggesting appropriate measures for the management of subareas 48.1 and 48.2. The present investigation was authorized by the Convention for the Conservation of Antarctic Marine Living Resources (CCAMLR) and by the Under-secretariat for Fisheries of Chile (SUBPESCA).

\section{MATERIALS AND METHODS}

\section{General aspects}

The study area comprised the continental shelf around Elephant Island and the South Orkney Islands (subareas 48.1 and 48.2) (Fig. 1). Sampling activities were carried out between 50 and $500 \mathrm{~m}$ depth, between January 10 and 21, 2018.

\section{Acoustic survey}

The acoustic information was obtained with a SIMRAD EK80 wide band scientific echosounder, at a frequency of $38 \mathrm{kHz}$ (ES38B), and a SIMRAD ES70 fishing echosounder equipped with a $120 \mathrm{kHz}$ frequency transducer (ES120-7C). The time varied gain (TVG) used corresponded to $20 \mathrm{LOG}$ for the detection of shoals (Reid et al., 1998; MacLennan et al., 2002;
Simmonds \& MacLennan, 2006; ICES, 2007). The ES70 equipment can detect individual targets and estimate the size of the observed organisms as an option available on the echosounder screen, which allows visualizing the lengths of the detected specimens in a frequency histogram (in centimeters) and thus allow to discriminate between Antarctic krill (Euphausia superba) and fish.

The acoustic survey covered the approximate area of the 50 and $500 \mathrm{~m}$ isobaths of depth, with a pulse length of $1,024 \mu \mathrm{s}$. The information was recorded during all navigation and fishing operations, and these tasks were complemented during the night for seabed recognition for the next day and shoal detection (fish and krill). Some identification hauls were carried out at the time of resource detection to reduce the spatiotemporal uncertainty in the allocation of the echointegration units.

The geo-referenced acoustic information (raw) was stored in magnetic files that were processed and analyzed on land. Data were analyzed through the Sonardata computer program; data referred to SA $\left(\mathrm{m}^{2}\right.$ $\mathrm{mn}^{-2}$ ) will be associated with each species identified in the echograms. Krill concentrations were detected considering their bathymetric distribution, shoal shape and individuals size structure, provided by the echosounder, and samples obtained with a midwater net. It is important to note that in some cases, the mackerel icefish Champsocephalus gunnari and pelagic finfish ("other finfish") shoals were identified exclusively through expert judgment. Concerning the echogram characteristics, the predominant use of bottom trawling nets resulted in a lack of the pelagic environment sampling.

\section{Fishing hauls}

Demersal finfish sampling was carried out using bottom trawl fishing gear, according to a stratified random sampling design. All hauls were carried out with an effective trawling time of 30 min during daylight hours. (nautical twilight to nautical sunset). Trawling was conducted only during daylight hours when fishes were known to concentrate on the bottom or in near-bottom layers, to be comparable with results of previous investigations, carried out in this way, in this same region (e,g., Jones et al., 1999a, 2001, 2003; Kock et al., 2002, 2007; Jones \& Kock, 2009; Kock \& Jones, 2012a). A hardbottom snapper trawl net (length $45 \mathrm{~m}$, horizontal mouth opening $11 \mathrm{~m}$, vertical mouth height of 8-9 $\mathrm{m}$, and $40 \mathrm{~mm}$ mesh size in the codend) (Net Systems, Inc., Bainbridge Island, WA), was used for the hauls; gear previously used in this area by the US AMLR Program, Southwest Fisheries Science Center, National Marine Fisheries Service, USA. 


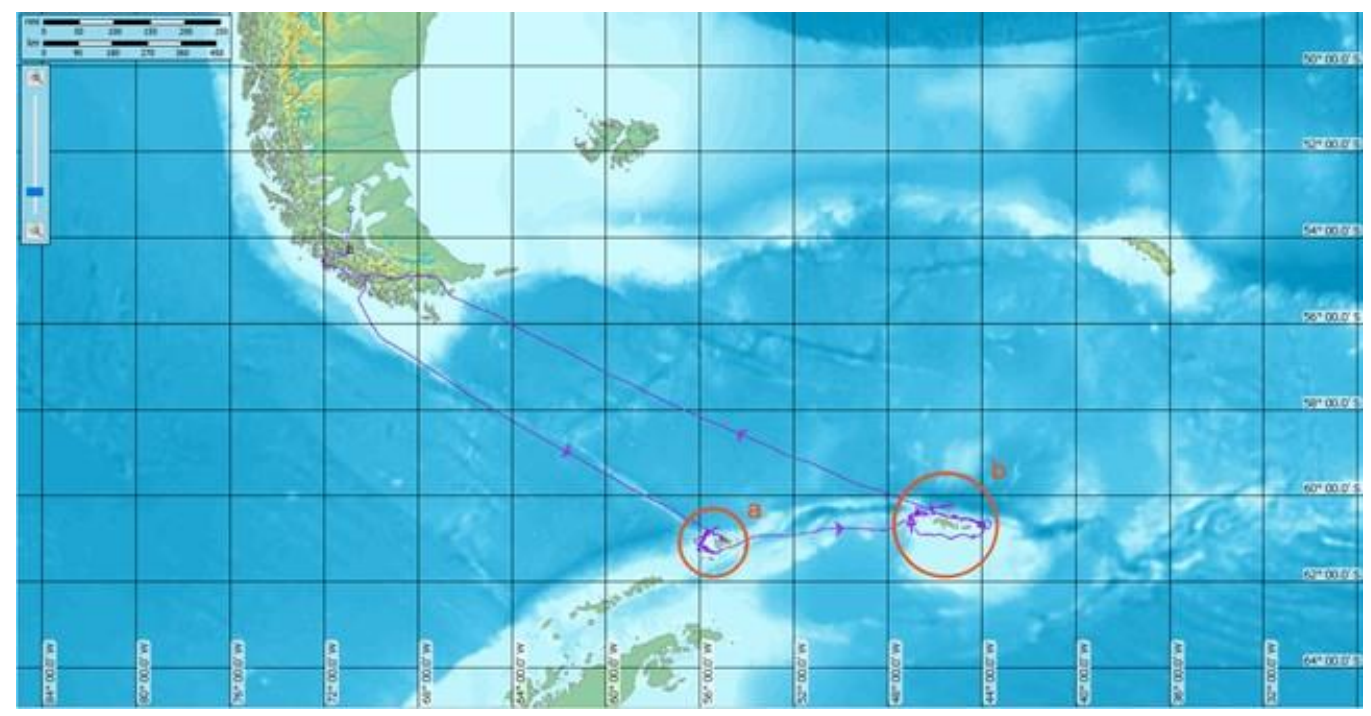

Figure 1. Navigation route of the research cruise. a) Elephant Island (Subarea 48.1), b) South Orkney Islands (Subarea 48.2).

After each haul, fishes were identified and sorted for species. Species identification was carried out to the most precise taxonomic level possible. Identification guides for the identification criteria were used for fish and other species (Fisher \& Hureau, 1985; CCAMLR, 2011a, 2013b; Dongwon, 2015) and fish juveniles and larvae (Iwami, 1995; Iwami \& Naganobu, 2007). Catch composition was recorded in terms of weight and number of individuals caught. In each haul, the catch per unit of effort (CPUE) was estimated as catch by haul $\left(\mathrm{kg} \mathrm{haul}^{-1}\right)$, catch by time $\left(\mathrm{kg} \mathrm{h}^{-1}\right)$, and catch by distance covered $\left(\mathrm{kg} \mathrm{km}^{-1}\right)$.

The seabed area surveyed during the haul was determined by the latitude/longitude coordinates taken as a straight line from the start to the end of the trawl's bottom contact, and the average of the trawl mouth width. We assumed a gear catchability of $100 \%$.

\section{Length and sex compositions}

Fish size was measured as total length (TL) in $\mathrm{cm}$ (from the tip of snout to end of caudal fin) and its total weight $(\mathrm{Wt})$ in grams. The length-frequency distributions were grouped per species and sampling area. Length-weight relationships were expressed using the standard allometric equation $\mathrm{Wt}=\mathrm{a} \times \mathrm{TL}^{\mathrm{b}}$. The Student's $t$-test $\left(t_{\alpha / 2}, n-2\right)$ was applied to establish the type of relative growth (allometric-isometric) characterizing the different species (Dixon \& Massey, 1957).

Sex and gonad maturity were determined using the five-point scale (immature, in development, developed, mature and post-spawning) of Kock \& Kellermann (1991). In the case of large catches, a representative sub-sample was randomly selected to determine the size and sex composition. Additionally, gonad and otolith samples were taken for reproductive and aging purposes.

\section{Environmental conditions}

Depth profiles of temperature and salinity were obtained in 19 trawling hauls around the South Orkney Islands by attaching a Seabird SBE 37SMP MicroCAT CTD to the upper part of the net.

\section{RESULTS}

\section{General aspects}

The cruise conducted between January 6 and 27, 2018, covering a total distance of approximately $3,496 \mathrm{~nm}$. The port of departure and return was Punta Arenas, Chile. The research was conducted aboard the Chilean factory ship Cabo de Hornos, an $80 \mathrm{~m}$-long stern trawler with 2,140 GRT, belonging to the fishing company Deris S.A. This vessel was equipped with two echo sounders (Simrad ES80, $38 \mathrm{kHz}$, and a Simrad ES70, $120 \mathrm{kHz}$ frequency) and a multi-frequency sonar (Furuno, FSV30, 21-27 kHz).

The bottom trawl survey included 36 hauls: 15 around Elephant Island (Subarea 48.1) and 21 around the South Orkney Islands (Subarea 48.2) (Fig. 2).

In Subarea 48.1 trawling depth ranged between 92 $\mathrm{m}$ and $415 \mathrm{~m}$, with the most frequent fishing hauls within 101-200 m (Fig 3a). In Subarea 48.2, trawling depth ranged between 106 and $425 \mathrm{~m}$, with the most frequent fishing hauls within 201-300 m (Fig. 3b). 

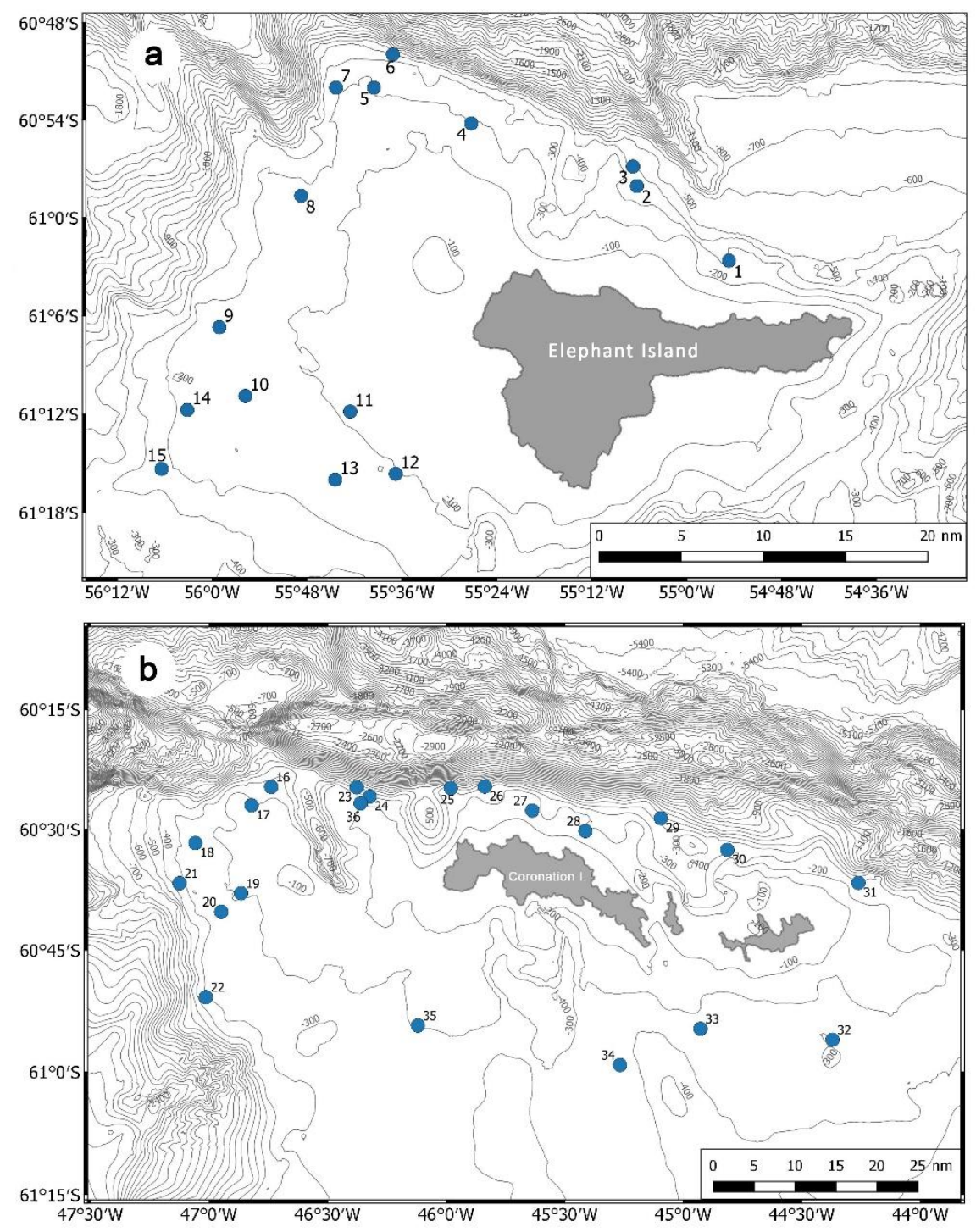

Figure 2. Bottom trawl sampling stations for the demersal finfish survey. a) Stations around the Elephant Island (Subarea 48.1), and b) stations around the South Orkney Islands (Coronation, Signy, Powell and Laurie islands) (Subarea 48.2).

\section{Acoustic survey}

The acoustic survey was carried out across the whole study area. The navigation route totaled $579 \mathrm{~nm}$ around Elephant Island and 1,120 nm (Fig. 4a) around the South Orkney Islands (Fig. 4b).

In the area around Elephant Island, the highest numbers of Champsocephalus gunnari were detected primarily around the west and northwestern sectors of the island and mostly associated with steep bathymetry (Fig. 4b). Only one haul allowed the positive identification of an icefish school (33.6 t). In the other four hauls, only some individuals of Pseudochaenichthys georgianus and Euphausia superba were detected. Other finfish without a clear definition of the species were recorded in the southwestern and south sectors of Elephant Island (Fig. 4d). Krill aggregations were observed along almost the entire navigation route of the ship, with more in the north and northwestern sector of the island (Fig. 4c).

Around the South Orkney Islands, the acoustic identification of $C$. gunnari concentrations was carried out based on expert judgment only, given that the largest number of aggregations were relatively far off the bottom ( $>8 \mathrm{~m})$, and above the mouth of the net used in the research. On this basis, the probable aggregations of mackerel icefish distributed primarily in the north and northwestern sectors of these islands (Fig. 5b). Krill concentrations were observed throughout the navigation route, especially in the northwestern and northeastern sectors (Fig. 5c). Records of possible other finfish were determined in two sectors, the first to the west-northwestern of these islands and the second to the east (Fig. 5c). 

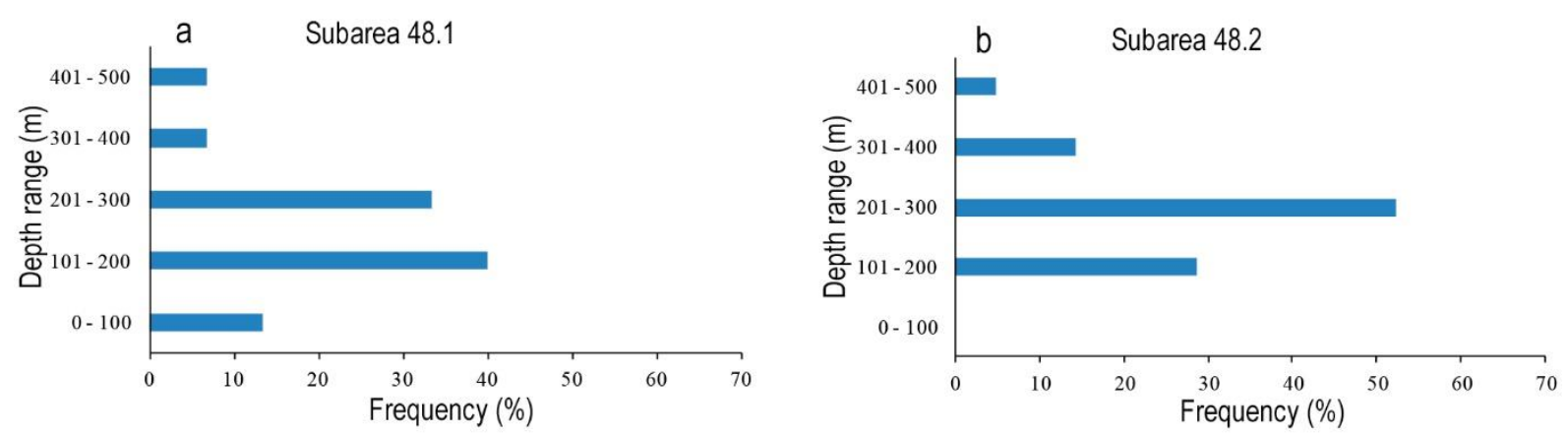

Figure 3. Distribution of trawling hauls by depth range for the demersal finfish survey. a) Subarea 48.1, b) Subarea 48.2.
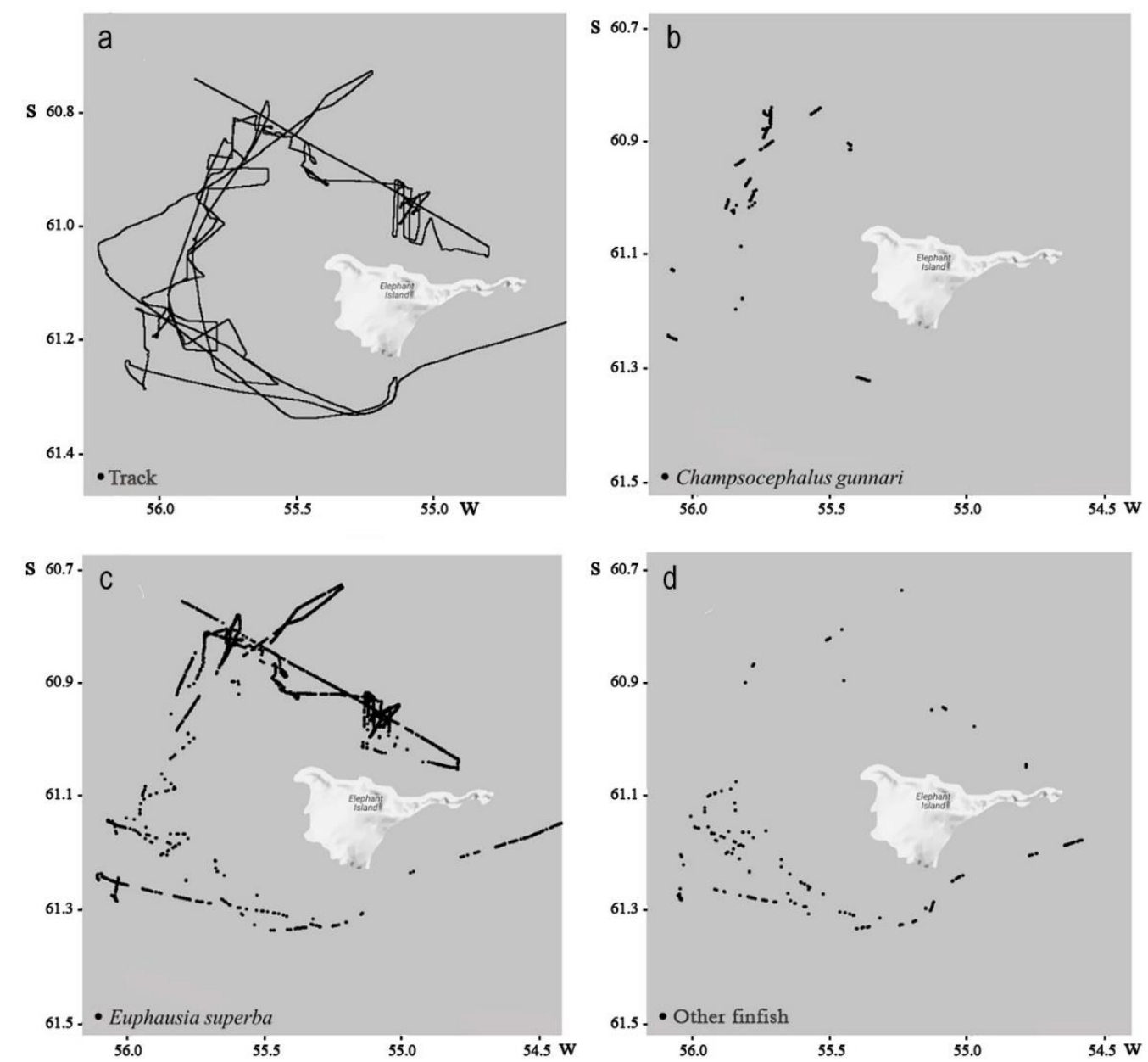

Figure 4. Spatial distribution of acoustic records of demersal fish and krill around Elephant Island. a) Acoustic track survey, b) mackerel icefish (Champsocephalus gunnari), c) Antarctic krill (Euphausia superba), d) other finfish.

\section{The effort, catch, and CPUE}

The total catch of all finfish species during the bottom trawl survey was $19,112.28 \mathrm{~kg}$; in Subarea 48.1, the amount was $17,305.7 \mathrm{~kg}$ and $1,806.58 \mathrm{~kg}$ in Subarea 48.2 (Table 1). A total of 37 fish species were identified, and size and sex were determined for 2,294 specimens.
Grouping catches obtained in both subareas, the main species caught were $N$. rossii and $C$. gunnari, with catches accounting for $16,204.38$ and $875.69 \mathrm{~kg}$, respectively. Other species recorded were Gobionotothen gibberifrons $(329.97 \mathrm{~kg})$, Chaenocephalus aceratus $(321.91 \mathrm{~kg})$ and Pseudochaenichthys georgianus $(299.39 \mathrm{~kg})$. 

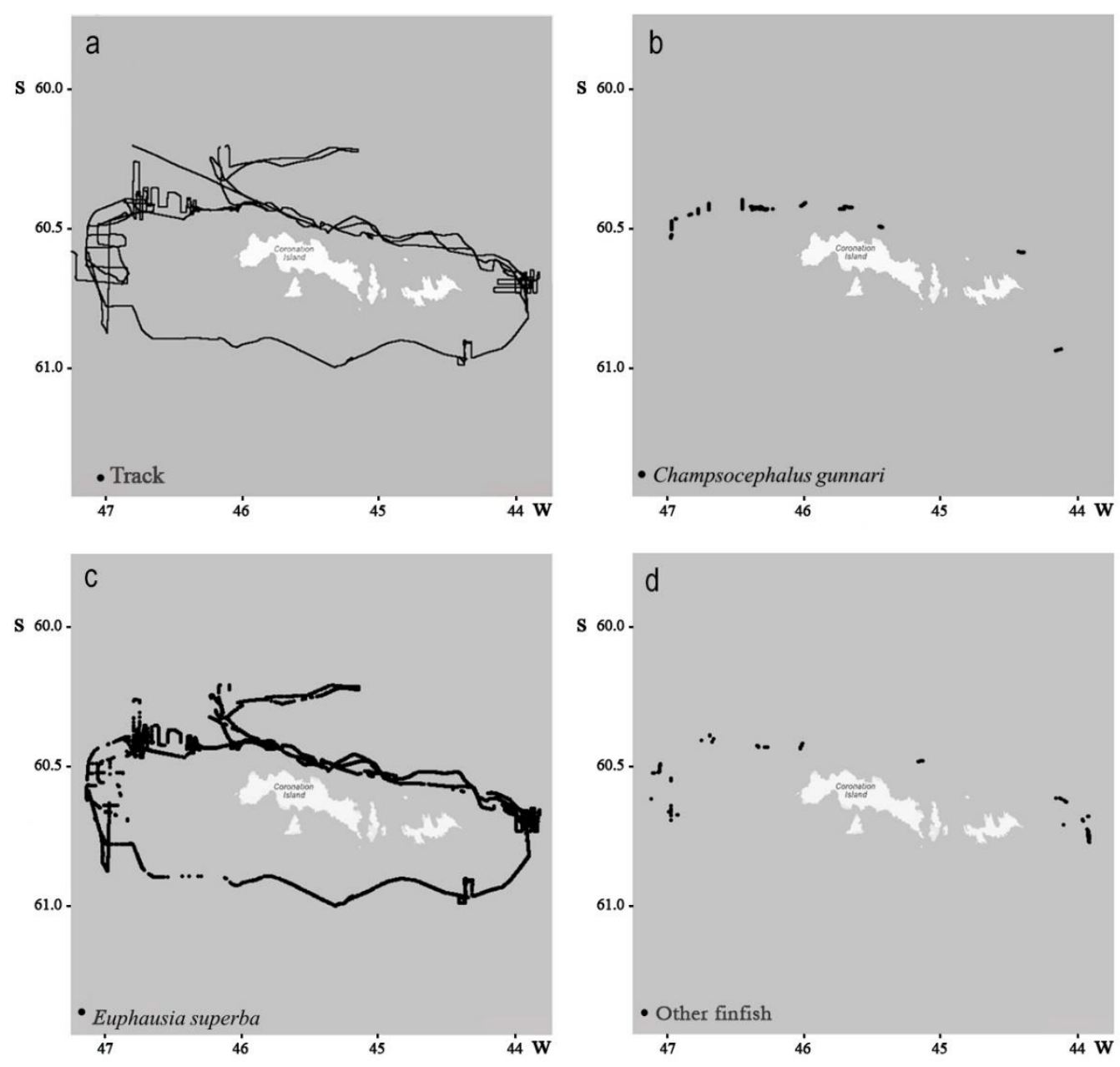

Figure 5. Spatial distribution of acoustic records of demersal fish and krill in the vicinity of the South Orkney Islands. a) Acoustic track survey, b) mackerel icefish (Champsocephalus gunnari), c) Antarctic krill (Euphausia superba), d) other finfish.

In terms of biomass, the main species caught in Subarea 48.1 were $N$. rossii and C. gunnari, which yielded a total of $16,197.81$ and $704.74 \mathrm{~kg}$, respectively. In Subarea 48.2, the catches mainly composed of G. gibberifrons (306.83 kg), P. georgianus (299.39 $\mathrm{kg})$, C. aceratus $(242.93 \mathrm{~kg})$ and C. gunnari $(170.95$ $\mathrm{kg})$.

Catch per unit effort, in terms of kilograms per trawling hour $\left(\mathrm{kg} \mathrm{h}^{-1}\right)$, showed marked differences between subareas (Table 2). In Subarea 48.1, the CPUE of $N$. rossii reached 2,159 $\mathrm{kg} \mathrm{h}^{-1}$, while in Subarea 48.2, this amount dropped to $0.62 \mathrm{~kg} \mathrm{~h}^{-1}$. C. gunnari showed a similar trend, decreasing from $93.96 \mathrm{~kg} \mathrm{~h}^{-1}$ in Subarea 48.1 to $16.25 \mathrm{~kg} \mathrm{~h}^{-1}$ in Subarea 48.2. An inverse evidence trend was recorded for G. gibberifrons, $P$. georgianus and $C$. aceratus, with the CPUE increasing in Subarea 48.2. By grouping both subareas, the highest
CPUE values were obtained for $N$. rossii and $C$. gunnari, reaching 899.24 and $48.6 \mathrm{~kg} \mathrm{~h}^{-1}$, respectively (Table 2).

The CPUE expressed as catch per trawling kilometer $\left(\mathrm{kg} \mathrm{km}^{-1}\right)$ showed a similar pattern. In Subarea 48.1, the CPUE reached $319.84 \mathrm{~kg} \mathrm{~km}^{-1}$ for $N$. rossii, decreasing to $0.10 \mathrm{~kg} \mathrm{~km}^{-1}$ in Subarea 48.2. The CPUE of C. gunnari was $13.92 \mathrm{~kg} \mathrm{~km}^{-1}$ in Subarea 48.1 and to $2.52 \mathrm{~kg} \mathrm{~km}^{-1}$ in Subarea 48.2. By pooling together both subareas, the CPUE for $N$. rossii and C. gunnari reached 136.72 and $7.39 \mathrm{~kg} \mathrm{~km}^{-1}$, respectively (Table 2). Considering all species the species caught, the CPUE accounted for $2,307.43 \mathrm{~kg} \mathrm{~h}^{-1}$ in Subarea 48.1 and $171.73 \mathrm{~kg} \mathrm{~h}^{-1}$ in Subarea 48.2. CPUE per trawling $\mathrm{km}$ in Subarea 48.1 reached $341.72 \mathrm{~kg} \mathrm{~km}^{-1}$ and only $26.61 \mathrm{~kg} \mathrm{~km}^{-1}$ in Subarea 48.2. 
Table 1. Catch $(\mathrm{kg})$ and specimens sampled by species, obtained with bottom trawling (Hardbottom Snapper Trawl) in subareas 48.1 and 48.2. Code: CCAMLR species code.

\begin{tabular}{|c|c|c|c|c|c|c|c|c|c|c|}
\hline \multirow[b]{2}{*}{ Species } & \multirow[b]{2}{*}{ Code } & \multicolumn{3}{|c|}{ Subarea 48.1} & \multicolumn{3}{|c|}{ Subarea 48.2} & \multicolumn{3}{|c|}{ Total } \\
\hline & & $\begin{array}{l}\text { Catch } \\
(\mathrm{kg})\end{array}$ & $\begin{array}{l}\text { Sampling } \\
(\mathrm{kg})\end{array}$ & $\mathrm{n}$ & $\begin{array}{l}\text { Catch } \\
(\mathrm{kg})\end{array}$ & $\begin{array}{l}\text { Sampling } \\
(\mathrm{kg})\end{array}$ & $\mathrm{n}$ & $\begin{array}{l}\text { Catch } \\
(\mathrm{kg})\end{array}$ & $\begin{array}{l}\text { Sampling } \\
(\mathrm{kg})\end{array}$ & $\mathrm{n}$ \\
\hline Notothenia rossii & NOR & $16,197.81$ & 794.42 & 326 & 6.57 & 6.57 & 2 & $16,204,38$ & 800.99 & 328 \\
\hline Chaenocephalus aceratus & SSI & 78.98 & 74.78 & 62 & 242.93 & 236.30 & 224 & 321.91 & 311.08 & 286 \\
\hline Lepidonotothen squamifrons & NOK & 8.13 & 3.29 & 7 & 112.95 & 59.07 & 107 & 121.08 & 62.36 & 114 \\
\hline Parachaenichthys charcoti & $\mathrm{PCH}$ & 1.55 & 1.19 & 8 & 0 & 0 & 0 & 1.55 & 1.19 & 8 \\
\hline Champsocephalus gunnari & ANI & 704.74 & 180.73 & 494 & 170.95 & 98.62 & 317 & 875.69 & 279.35 & 811 \\
\hline Lepidonotothen larseni & NOL & 3.63 & 0.66 & 16 & 22.02 & 1.25 & 19 & 25.64 & 1.90 & 35 \\
\hline Chionodraco rastrospinosus & KIF & 7.17 & 3.37 & 7 & 70.68 & 52.38 & 103 & 77.85 & 55.75 & 110 \\
\hline Dissostichus mawsoni & TOA & 53.26 & 3.77 & 3 & 0 & 0 & 0 & 53.26 & 3.77 & 3 \\
\hline Octopodidae & OCT & 16.75 & 0 & 0 & 12.13 & 0 & 0 & 28.88 & 0 & 0 \\
\hline Gymnoscopelus nicholsi & GYN & 48.62 & 0 & 0 & 20.23 & 0.04 & 1 & 68.85 & 0.04 & 1 \\
\hline Bathyraja eatonii & BEA & 0 & 0 & 0 & 0.96 & 0.96 & 2 & 0.96 & 0.96 & 2 \\
\hline Trematomus eulepidotus & TRL & 0 & 0 & 0 & 19.82 & 2.63 & 13 & 19.82 & 2.63 & 13 \\
\hline Bathyraja maccaini & BAM & 3.25 & 0 & 0 & 15.20 & 0.46 & 1 & 18.45 & 0.46 & 1 \\
\hline Bathyraja spp. & BHY & 2.18 & 0 & 0 & 0 & 0 & 0 & 2.18 & 0 & 0 \\
\hline Ophthalmolycus amberensis & LYA & 1.81 & 0.82 & 2 & 0 & 0 & 0 & 1.81 & 0.82 & 2 \\
\hline Muraenolepis microps & MOY & 1.64 & 1.64 & 4 & 4.60 & 2.30 & 7 & 6.24 & 3.94 & 11 \\
\hline Gobionotothen gibberifrons & NOG & 23.14 & 20.43 & 25 & 306.83 & 42.39 & 186 & 329.97 & 62.81 & 211 \\
\hline Notothenia coriiceps & NOC & 50.92 & 48.88 & 36 & 11.41 & 11.12 & 6 & 62.34 & 60.01 & 42 \\
\hline Pachycara brachycephalum & PHB & 0.10 & 0 & 0 & 0 & 0 & 0 & 0.1 & 0 & 0 \\
\hline Nototheniops nudifrons & NOD & 0.60 & 0.60 & 12 & 0.92 & 0.81 & 8 & 1.51 & 1.40 & 20 \\
\hline Cryodraco antarcticus & FIC & 0.38 & 0.38 & 10 & 1.44 & 1.22 & 14 & 1.82 & 1.60 & 24 \\
\hline Cephalopoda & CEP & 1.18 & 0 & 0 & 0 & 0 & 0 & 1.18 & 0 & 0 \\
\hline Notothenia acuta & NOA & 0.16 & 0.16 & 1 & 0 & 0 & 0 & 0.16 & 0.16 & 1 \\
\hline Pseudochaenichthys georgianus & SGI & 0 & 0 & 0 & 299.39 & 294.02 & 242 & 299.39 & 294.02 & 242 \\
\hline Notothenia squamifrons & NOS & 0 & 0 & 0 & 1.71 & 1.71 & 12 & 1.71 & 1.71 & 12 \\
\hline Pogonophryne marmorata & PGM & 0 & 0 & 0 & 0.35 & 0.35 & 1 & 0.35 & 0.35 & 1 \\
\hline Trematomus hansoni & TRH & 0 & 0 & 0 & 3.93 & 3.93 & 6 & 3.93 & 3.93 & 6 \\
\hline Pleuragramma antarcticum & ANS & 0 & 0 & 0 & 4.56 & 0 & 0 & 4.56 & 0 & 0 \\
\hline Trematomus newnesi & TRW & 0 & 0 & 0 & 0.11 & 0.11 & 1 & 0.11 & 0.11 & 1 \\
\hline Neopagetopsis ionah & JIC & 0 & 0 & 0 & 0.43 & 0.43 & 2 & 0.43 & 0.43 & 2 \\
\hline Bathydraco antarcticus & $\mathrm{BDN}$ & 0 & 0 & 0 & 0.18 & 0.18 & 1 & 0.18 & 0.18 & 1 \\
\hline Pogonophryne spp. & POG & 0 & 0 & 0 & 0.41 & 0.41 & 1 & 0.41 & 0.41 & 1 \\
\hline Raja spp. & RAJ & 0 & 0 & 0 & 0.02 & 0 & 0 & 0.02 & 0 & 0 \\
\hline Paraliparis spp. & PVZ & 0 & 0 & 0 & 0.02 & 0.02 & 1 & 0.02 & 0.02 & 1 \\
\hline Pogonophryne scotti & $\mathrm{SZT}$ & 0 & 0 & 0 & 0.30 & 0.30 & 1 & 0.30 & 0.30 & 1 \\
\hline Racovitzia glacialis & RGG & 0 & 0 & 0 & 0.24 & 0.24 & 2 & 0.24 & 0.24 & 2 \\
\hline Macrourus whitsoni & WGR & 0 & 0 & 0 & 0 & 0 & 0 & 0 & 0 & 0 \\
\hline Anotopterus pharao & ANH & 0 & 0 & 0 & 0.60 & 0.60 & 1 & 0.60 & 0.60 & 1 \\
\hline Macrourus holotrachys & $\mathrm{MCH}$ & 0 & 0 & 0 & 0 & 0 & 0 & 0 & 0 & 0 \\
\hline Bentos & BEN & 99.75 & 0 & 0 & 474.73 & 0 & 0 & 574.47 & 0 & 0 \\
\hline Total & & $17,305.70$ & $1,135.10$ & 1.013 & $1,806.58$ & 818.35 & 1281 & $19,112.28$ & $1,953.45$ & 2294 \\
\hline
\end{tabular}

\section{Standing stock biomass}

In both subareas, we were unable to complete the planned number of stations because of limited ship time and ice conditions, which resulted in a low number of sampling stations from which to estimate standing stock biomass (Elephant Island: 13 stations; South Orkney Islands: 21 stations). For this reason, the results presented in Table 3 should be taken only as indicative.
Estimates of standing stock biomass were computed using the Delta log normal maximum likelihood estimator (De la Mare, 1994; Pennington, 1996). Seabed areas of the Elephant Island shelf were drawn from Jones et al. (1999), and seabed areas on the South Orkney Islands shelf were drawn from Jones (2000).

Indicative estimates of demersal finfish standing stock biomass, around Elephant Island and the South 
Table 2. Catch per unit of effort (CPUE) of Champsocephalus gunnari, Notothenia rossii, Chaenocephalus aceratus, Pseudochaenichthys georgianus and Gobionotothen gibberifrons in subareas 48.1 and 48.2.

\begin{tabular}{lcrrr}
\hline Species & Subarea & Catch $(\mathrm{kg})$ & CPUE $\left(\mathrm{kg} \mathrm{h}^{-1}\right)$ & CPUE $\left(\mathrm{kg} \mathrm{km}^{-1}\right)$ \\
\hline Champsocephalus gunnari & 48.1 & 704.74 & 93.96 & 13.92 \\
& 48.2 & 170.95 & 16.25 & 2.52 \\
\cline { 2 - 5 } & Total & 875.69 & 48.60 & 7.39 \\
\hline Notothenia rossii & 48.1 & $16,197.81$ & $2,159.71$ & 319.84 \\
& 48.2 & 6.57 & 0.62 & 0.097 \\
\cline { 2 - 5 } Chaenocephalus aceratus & Total & $16,204.38$ & 899.24 & 136.72 \\
& 48.1 & 78.98 & 10.53 & 1.56 \\
& 48.2 & 242.93 & 23.09 & 3.58 \\
\hline Pseudochaenichthys georgianus & Total & 321.91 & 17.86 & 2.72 \\
& 48.1 & 0 & 0 & 0 \\
& 48.2 & 299.39 & 28.46 & 4.41 \\
\cline { 2 - 5 } & Total & 299.39 & 16.61 & 2.53 \\
\hline Gobionotothen gibberifrons & 48.1 & 23.14 & 3.09 & 0.46 \\
& 48.2 & 306.83 & 29.17 & 4.52 \\
\cline { 2 - 5 } & Total & 329.97 & 18.31 & 2.78 \\
\hline
\end{tabular}

Table 3. Indicative estimates of total stock biomass (t) for eight primary demersal species from the 2018 bottom trawl surveys of Elephant Island and the South Orkney Islands.

\begin{tabular}{llccc}
\hline Area & \multicolumn{1}{c}{ Species } & Abundance (t) & Standard error & 95\% Confidence interval \\
\hline & Chaenocephalus aceratus & 453 & 189 & $1,615-79,662$ \\
& Champsocephalus gunnari & 6.333 & 4.134 & $17-123$ \\
& Chionodraco rastrospinosus & 54 & 28 & $52-885$ \\
Elephant Island & Gobionotothen gibberifrons & 167 & 91 & $9-88$ \\
& Lepidonotothen larseni & 23 & 10 & $21-2,861$ \\
& Lepidonotothen squamifrons & 103 & 75 & $95-2,422$ \\
& Notothenia coriiceps & 318 & 184 & $55,362-16,526,300$ \\
\hline Notothenia rossii & 376.229 & 302.509 & $3,482-18,373$ \\
& Chaenocephalus aceratus & 6.716 & 2.391 & $2,149-12,318$ \\
& Champsocephalus gunnari & 4.242 & 1.572 & $5,248-37,693$ \\
& Gobionotothen gibberifrons & 11.145 & 4.568 & $288-2,421$ \\
& Lepidonotothen larseni & 654 & 283 & $1,388-22,266$ \\
& Lepidonotothen squamifrons & 3.936 & 2.062 & $67-4,821$ \\
& Notothenia coriiceps & 309 & 214 & $28-466$ \\
& Notothenia rossii & 161 & 113 & $4,073-53,329$ \\
\hline
\end{tabular}

Orkney Islands, suggest that $N$. rossii, followed by $C$. gunnari, are the most abundant finfish species in the Elephant Island area sampled as part of the bottom trawl survey. Conversely, the most abundant species on the South Orkney Island shelf was G. gibberifrons followed by $P$. georgianus (Table 3).

\section{Length frequency distribution}

In Subarea 48.1, the total lengths (TL) of $N$. rossii males reached an average of $52.16 \mathrm{~cm}$ with a range between 23 and $71 \mathrm{~cm}$. The females of this species were larger, reaching an average size of $57.35 \mathrm{~cm}$ with a range between 35 and $79 \mathrm{~cm}$ TL (Figs. 6a-b). There were no distinct modes in the length distributions of this species.

Regarding C. gunnari, males caught in Subarea 48.1 varied between 18 and $53 \mathrm{~cm}$ TL with an average of $34.56 \mathrm{~cm}$. The size of females ranged between 18 and $55 \mathrm{~cm}$, with an average size of $33.67 \mathrm{~cm}$ TL (Figs. 7ab). Both sexes present a strong modal between 32 and $34 \mathrm{~cm} \mathrm{TL}$, likely representing a three years class. There was also evidence of a mode at around $48-50 \mathrm{~cm}$ TL, which could indicate the existence of another annual class in that length range. 

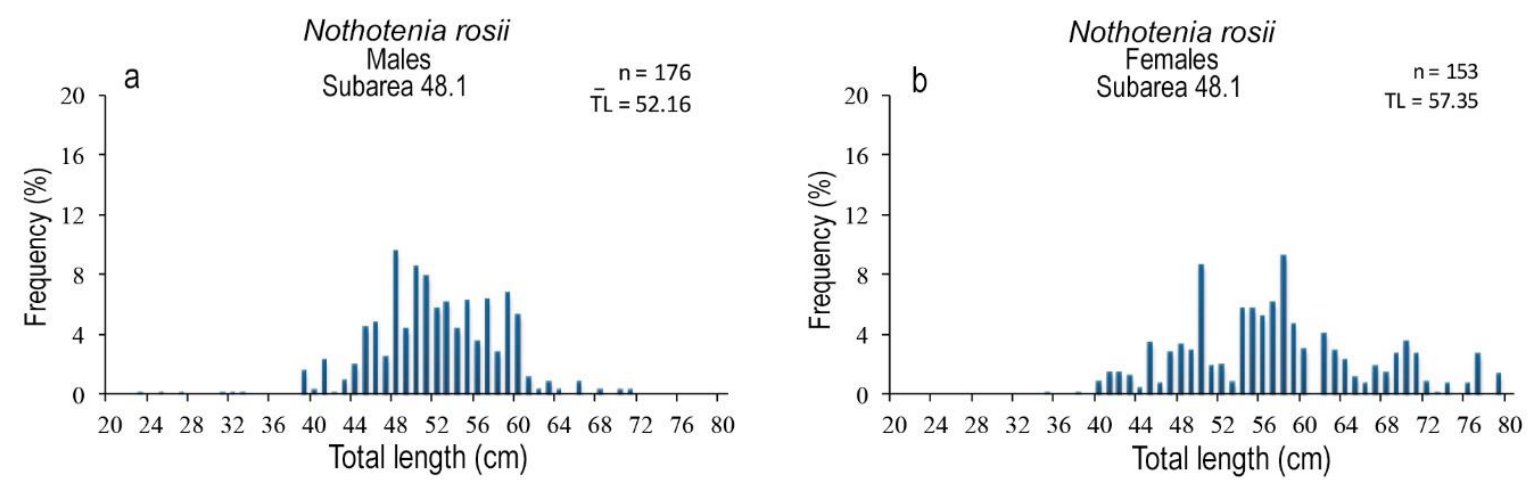

Figure 6. Total length (TL, cm) frequency distributions of Notothenia rossii in Subarea 48.1. a) male, b female).
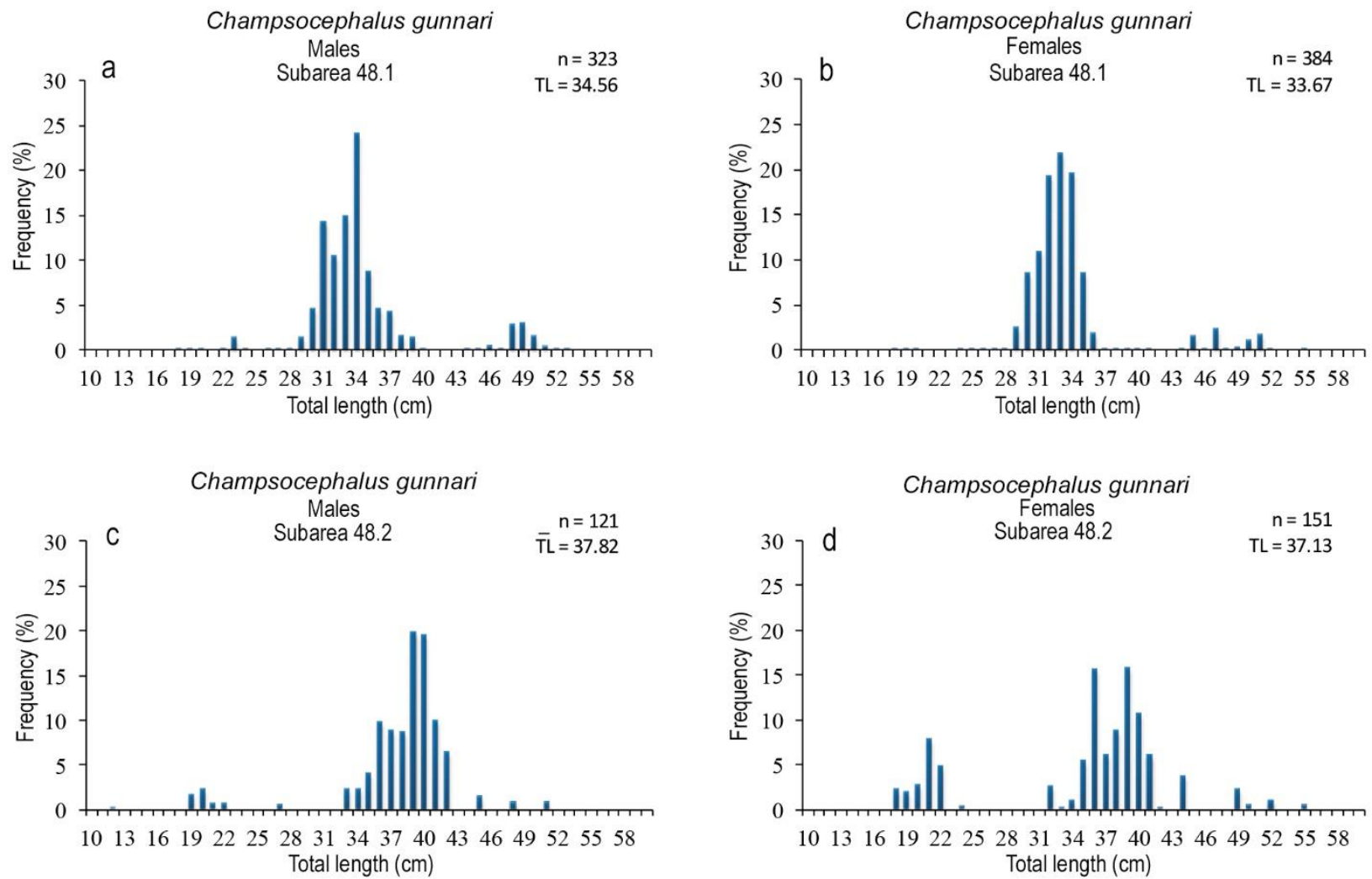

Figure 7. Total length (TL, cm) frequency distributions (male and female) of Champsocephalus gunnari. a-b) Subarea 48.1, c-d) Subarea 48.2.

In Subarea 48.2, the males of $C$. gunnari measured between 12 and $51 \mathrm{~cm}$ with an average of $37.82 \mathrm{~cm} \mathrm{TL}$, while the females showed a length range of 18 to $55 \mathrm{~cm}$ with an average of $37.13 \mathrm{~cm}$ (Figs. 7c-d). As in the previous subarea, the size of males roughly follows a normal distribution with a peak between 36 and $40 \mathrm{~cm}$ $\mathrm{TL}$, and in females, a lesser peak between 18 and $22 \mathrm{~cm}$ TL is distinguished.

It should be noted that in hauls 11-13, carried out between 92 and $135 \mathrm{~m}$ to the southwestern of Elephant
Island (Fig. 2), the catch was almost exclusively composed of juveniles. The TL in these hauls was between 5 and $13 \mathrm{~cm}$, with an average of $8.27 \mathrm{~cm}$ of TL, clearly different from the average already previously indicated in adjacent areas of this same subarea (Fig. 8).

The size range of $C$. aceratus males was between 19 and $65 \mathrm{~cm}$, with an average of $44.10 \mathrm{~cm}$ TL. The females showed a larger size, with total lengths of 14 to $71 \mathrm{~cm}$ and an average of $57.2 \mathrm{~cm}$ TL (Figs. 9a-b). 

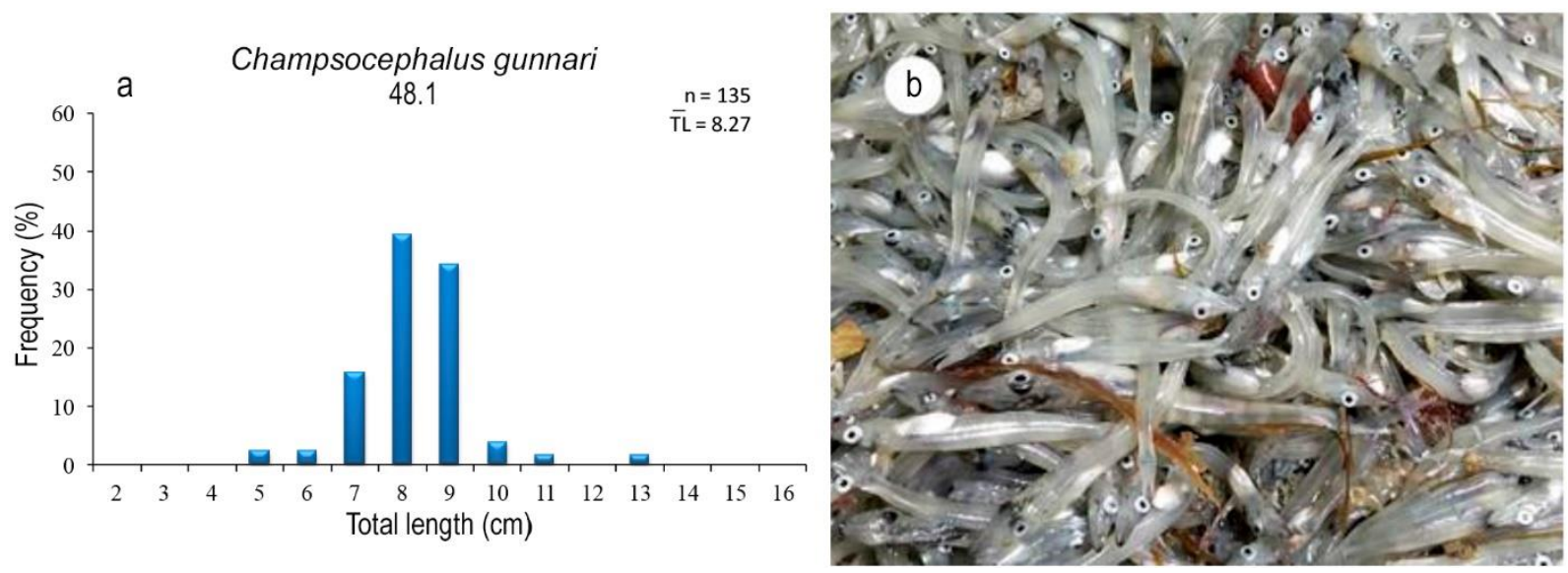

Figure 8. a) Total length (TL, cm) frequency distributions of Champsocephalus gunnari between 92 and $135 \mathrm{~m}$ deep in the SW of Elephant Island (hauls 11-13), b) small specimens captured (Photo: C.D. Jones).

Specimens of Pseudochaenichthys georgianus were only obtained in Subarea 48.2. The total length range in males was 14 to $58 \mathrm{~cm}$, with an average of $47.54 \mathrm{~cm}$, and in females was 25 to $63 \mathrm{~cm}$ with an average of $49.35 \mathrm{~cm}$ TL (Figs. 9c-d).

Due to the limited number of individuals of Gobionotothen gibberifrons captured, samples obtained in both subareas were grouped for their analysis. Size for both sexes ranged between 17 and $50 \mathrm{~cm}$ TL, with averages of $35.31 \mathrm{~cm}$ for males and $29.95 \mathrm{~cm}$ for females. Noteworthy in these distributions is the presence of a mode of large males between 48 and 50 cm TL (Figs. 9e-f).

The total length range (TL, $\mathrm{cm}$ ) of the different species of fish caught on the cruise is shown in Table 4.

\section{Sex ratio}

The analysis of the catch records of $N$. rossii in Subarea 48.1 shows that $53.5 \%$ of the specimens were males, and $46.5 \%$ were females.

In the case of $C$. gunnari, females predominated in the sample carried out in Subarea 48.1, with $54.3 \%$ of the examined specimens and the remaining $45.7 \%$ corresponding to males. The same situation was observed in Subarea 48.2, where the total of females reached $55.5 \%$ and the males $44.5 \%$.

Regarding G. gibberifrons, when grouping the samples obtained in both subareas, a relative predominance of males was observed (53.6\%). The same situation was observed in $P$. georgianus (58.6\%). The sex ratio recorded for $C$. aceratus was close to $1: 1$, being 49.6 and $50.4 \%$ of males and females, respectively.

\section{Gonad maturity stages}

The 5-point scale described by Kock \& Kellerman (1991) for nototheniids and channichthyids was used to determine the maturity stages of the species captured during the cruise. In the case of $C$. gunnari, the majority (between 60 and 70\%) of specimens were in a developing stage and only a few specimens in the developed and mature stage (Fig. 10a).

Regarding $C$. aceratus, differences in maturity between sexes were observed; approximately $50 \%$ of males and $21 \%$ of females exhibited developing gonads, while females showed the highest preponderance (50\%) in the developed stage (Fig. 10b).

On the other hand, males and females of $N$. rossii were mainly found in developing and developed stage, the latter constituting between 58 and $68 \%$ of the total (males and females, respectively) (Fig. 10c).

In $P$. georgianus, developing males were approximately $65 \%$ of the total, followed by the immature stage $(20 \%)$. In females, developed specimens were $48 \%$ of the total and $37.6 \%$ in the developing stage (Fig. $10 \mathrm{~d})$.

The species $G$. gibberifrons exhibited similar patterns, with both sexes reaching $70 \%$ of the specimens in the developing stage and other $(20 \%)$ in the immature stage (Fig. 10e).

\section{Length-weight relationship}

The total length (TL) and total weight (Wt) records of the species with the highest catch biomass from both subareas (48.1 and 48.2) were grouped for C. gunnari, $N$. rossii, C. aceratus, P. georgianus, and G. gibberifrons.

A total of 964 specimens of $C$. gunnari were measured and weighed (437 males and 527 females). In 

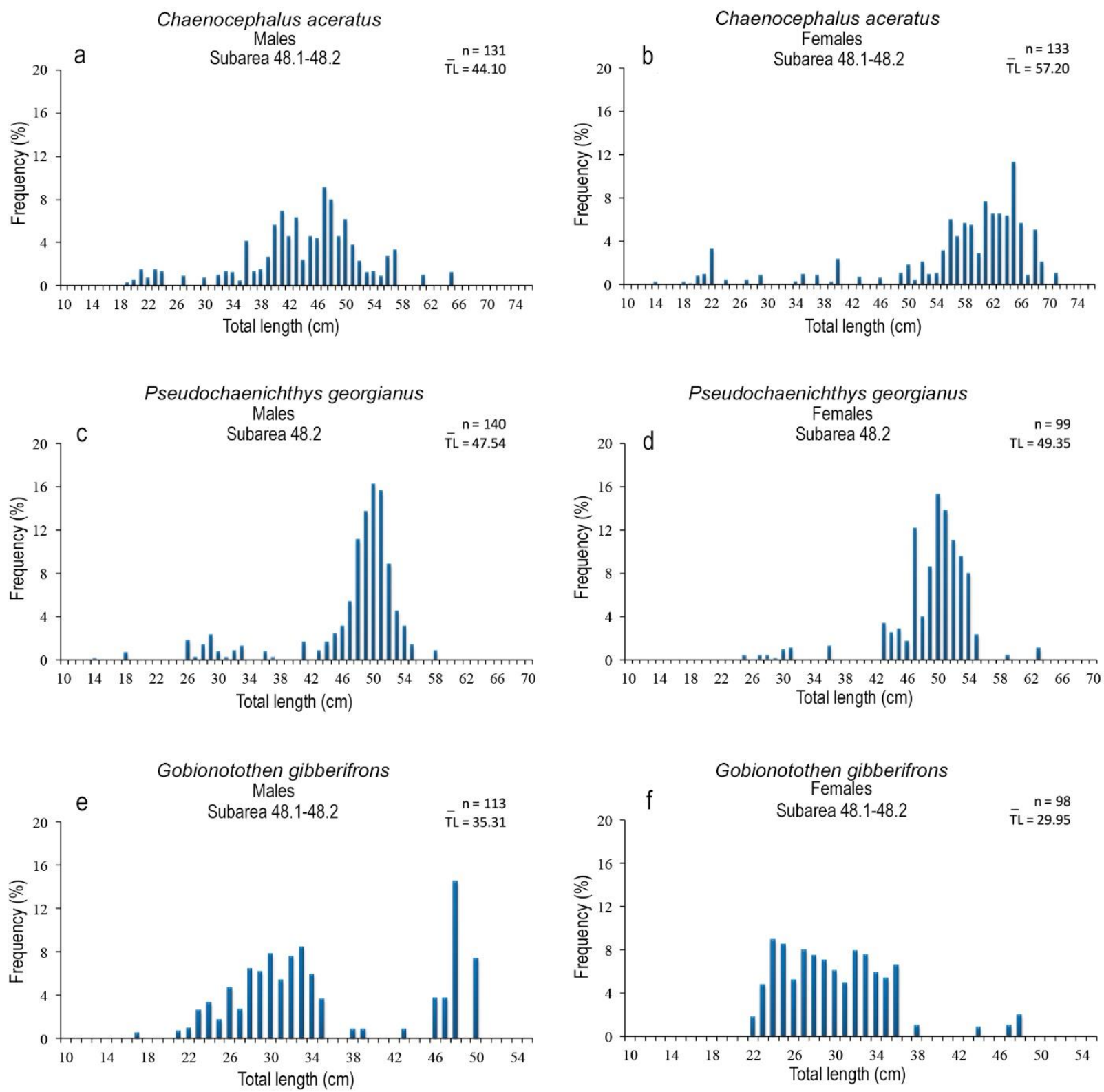

Figure 9. Total length (TL, cm) frequency distribution of males and females of a-b) Chaenocephalus aceratus grouped in both subareas, c-d) Pseudochaenichthys georgianus in Subarea 48.2, e-f) Gobionotothen gibberifrons grouped in both subareas.

the length-weight relationships, the coefficients of determination were 0.96 (males) and 0.94 (females), and the parameter $b$ was 3.289 and 3.112 in males and females, respectively. Males presented positive allometry $(b>3)$, and whereas females showed isometry $(b$ = 3) (Table 5, Figs. 11a-b).

In the case of $N$. rossii, a total of 178 males and 153 females were measured and weighed. In the lengthweight relationships, the coefficients of determination were 0.97 and 0.96 for males and females, respectively, and the parameter $b$ was 3.018 in males and 2.935 in females. Both sexes exhibit and isometric growth $(b=$ 3) (Table 5, Figs. 11c-d).

Regarding C. aceratus, 131 males and 133 females were analyzed, with coefficients of determination corresponding to 0.98 and 0.99 , respectively. The parameter $b$ was 3.754 in males and 3.590 in females. Positive allometric growth $(b>3)$ was observed in both sexes (Table 5, Figs. 11e-f).

For the length-weight relationship analysis in $P$. georgianus, 140 males and 99 females were sampled. 
Table 4. Total length range (TL, $\mathrm{cm}$ ) of the different species of fish caught on the cruise.

\begin{tabular}{|c|c|c|}
\hline Species & $\begin{array}{c}\text { Minimum } \\
\text { length }(\mathrm{cm})\end{array}$ & $\begin{array}{r}\text { Maximum } \\
\text { length }(\mathrm{cm})\end{array}$ \\
\hline Notothenia rossii & 23 & 79 \\
\hline Chaenocephalus aceratus & 14 & 71 \\
\hline Lepidonotothen squamifrons & 12 & 51 \\
\hline Parachaenichthys charcoti & 17 & 39 \\
\hline Champsocephalus gunnari & 5 & 55 \\
\hline Lepidonotothen larseni & 12 & 28 \\
\hline Chionodraco rastrospinosus & 14 & 52 \\
\hline Dissostichus mawsoni & 24 & 101 \\
\hline Gymnoscopelus nicholsi & & 16 \\
\hline Bathyraja eatonii & 31 & 38 \\
\hline Trematomus eulepidotus & 18 & 29 \\
\hline Bathyraja maccaini & & 38 \\
\hline Ophthalmolycus amberensis & 19 & 28 \\
\hline Muraenolepis microps & 22 & 44 \\
\hline Gobionotothen gibberifrons & 17 & 50 \\
\hline Notothenia coriiceps & 32 & 55 \\
\hline Nototheniops nudifrons & 10 & 28 \\
\hline Cryodraco antarcticus & 15 & 35 \\
\hline Notothenia acuta & & 23 \\
\hline Pseudochaenichthys georgianus & 14 & 63 \\
\hline Notothenia squamifrons & 17 & 23 \\
\hline Pogonophryne marmorata & & 27 \\
\hline Trematomus hansoni & 26 & 44 \\
\hline Trematomus newnesi & & 21 \\
\hline Neopagetopsis ionah & 20 & 25 \\
\hline Bathydraco antarcticus & & 20 \\
\hline Pogonophryne spp. & & 29 \\
\hline Paraliparis spp. & & 11 \\
\hline Pogonophryne scotti & & 27 \\
\hline Racovitzia glacialis & 23 & 33 \\
\hline Macrourus whitsoni & & 14 \\
\hline Anotopterus pharao & 40 & 101 \\
\hline Macrourus holotrachys & 7 & 9.5 \\
\hline
\end{tabular}

The coefficient of determination was 0.95 in males and 0.97 in females, while the parameter $b$ was 3.257 and 3.699 , respectively. Positive allometric growth $(b>3)$ was determined for both sexes (Table 5, Figs. 11g-h).

For G. gibberifrons a total of 113 males and 98 females were measured and weighed. The respective coefficients of determination were 0.97 and 0.96 , while the parameter $b$ was of 3.521 and 3.304, respectively. Positive allometric growth was found in both sexes $(b$ > 3) (Table 5, Figs. 11i-j).

The average weights determined for the different species caught during the survey are set out in Table 6.

\section{Environmental conditions}

Depth profiles of temperature, salinity, and density and the average curve for these parameters are shown around the South Orkney Islands (Fig. 12). In the depth range at which the trawls were carried out, it is worth noting that at $200 \mathrm{~m}$ depth waters were characterized by average values of temperature of $-0.6^{\circ} \mathrm{C}$ and salinity of 34.45 , whereas at $500 \mathrm{~m}$ average values were $0.45^{\circ} \mathrm{C}$ and 34.68 , respectively.

\section{DISCUSSION}

Since the 1989/1990 season, direct fishing of Champsocephalus gunnari, Dissostichus eleginoides, Dissostichus mawsoni, Electrona carlsbergi, Gobionotothen gibberifrons, Lepidonotothen squamifroms, Notothenia rossii, Patagonotothen guntheri, Pseudochaenichthys georgianus and other species of finfish has been prohibited in several subareas and divisions of the Southern Ocean (CCAMLR Conservation measure 32-02). This measure also indicates that this prohibition shall not apply to the taking of specified taxa for scientific research under Conservation Measure 24-01. Since then, several investigations have been carried out in subareas 48.1 and 48.2 , to monitor the recovery and status of Antarctic fish populations. Kock \& Jones (2005) published a comprehensive review of the results obtained from historical research surveys carried out on demersal fish around the South Shetland Islands, Elephant Island, and the South Orkney Islands.

The present survey was carried out following the general guidelines recommended by the CCAMLR Scientific Committee, which consist of using the same bottom trawl net used previously in the evaluation of the demersal fish community (Hardbottom Snapper Trawl). For comparative purposes, the sampling station was set at approximately the same geographic coordinates used previously.

It is noticeable that a substantial diversity of species was caught using a bottom trawl net, with a total of 36 species of fish caught during the cruise, 15 of them present on the Elephant Island shelf, and 27 around the South Orkney Islands. Likewise, the difference in species composition and relative abundance was evident when comparing the catches made between the two surveyed areas (Table 1).

Catches composition by species was dependent on the depth strata at which the haul was made, and on geographical location. Interestingly, the marbled rockcod (N. rossii) was the only species that showed a considerable abundance around Elephant Island. However, it was almost enterally absent in the samples collected around the South Orkney Islands, registering only the presence of two individuals. A lower abundance of the mackerel icefish (C. gunnari) around Elephant Island was observed, while it was practically 

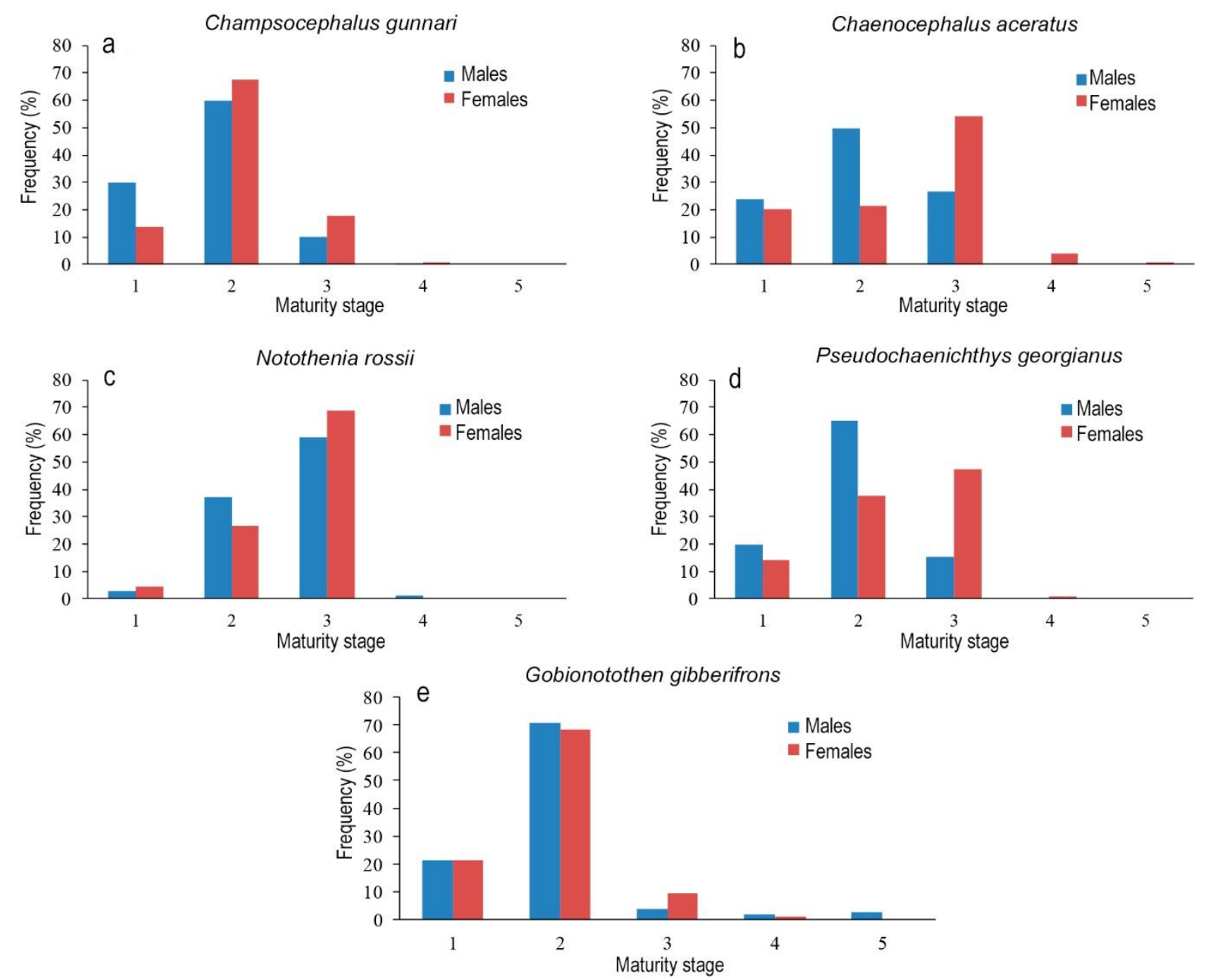

Figure 10. Maturity stage distribution of a) Champsocephalus gunnari, b) Chaenocephalus aceratus, c) Notothenia rossii, d) Pseudochaenichthys georgianus, and e) Gobionotothen gibberifrons. 1: immature; 2: developing or resting; 3: developed; 4: mature; 5: post-spawning (Kock \& Kellerman, 1991).

Table 5. Total length-total weight relationship of the principal species caught on the cruise. a: intercept, b: slope, $R^{2}$ : coefficient of determination.

\begin{tabular}{|c|c|c|c|c|c|c|c|c|c|}
\hline \multirow{2}{*}{ Species } & \multirow{2}{*}{ Subarea } & \multicolumn{4}{|c|}{ Males } & \multicolumn{4}{|c|}{ Females } \\
\hline & & Sample (n) & $\mathrm{a}$ & $\mathrm{b}$ & $\mathrm{R}^{2}$ & Sample (n) & $\mathrm{a}$ & $\mathrm{b}$ & $\mathrm{R}^{2}$ \\
\hline Champsocephalus gunnari & $48.1-48.2$ & 437 & $2.21 \times 10^{-6}$ & 3.29 & 0.96 & 527 & $4.18 \times 10^{-6}$ & 3.11 & 0.94 \\
\hline Notothenia rossii & $48.1-48.2$ & 178 & $1.36 \times 10^{-5}$ & 3.02 & 0.97 & 153 & $1.90 \times 10^{-5}$ & 2.93 & 0.96 \\
\hline Chaenocephalus aceratus & $48.1-48.2$ & 131 & $3.95 \times 10^{-7}$ & 3.75 & 0.98 & 133 & $7.11 \times 10^{-7}$ & 3.59 & 0.99 \\
\hline Pseudochaenichthys georgianus & 48.2 & 140 & $4.06 \times 10^{-6}$ & 3.26 & 0.95 & 99 & $6.82 \times 10^{-7}$ & 3.70 & 0.97 \\
\hline Gobionotothen gibberifrons & $48.1-48.2$ & 113 & $1.57 \times 10^{-6}$ & 3.52 & 0.97 & 98 & $3.16 \times 10^{-6}$ & 3.30 & 0.96 \\
\hline
\end{tabular}

absent in the waters surrounding the South Orkney Islands. This situation during a survey undertaken in 2016 was different, where a great abundance of this species was observed around both islands. However, this survey was conducted using a mid-water trawl and a different sampling design (Arana et al., 2016). Differences in the values obtained from CPUE and in the acoustic records between both expeditions should be verified in the future.
$N$. rossii tends to aggregate in high numbers in somewhat limited areas, as was noted by Jones et al. (2001). On this occasion, the highest concentrations were recorded between 100 and $400 \mathrm{~m}$ of depth to the north and northwest of Elephant Island with high yields. During a single half-hour trawl, the catch reached a maximum of 3,569 $\mathrm{kg}$. Previously, Jones et al. (2001) also documented dense aggregations of marbled rockcod at 230-320 m depth north of this island. 

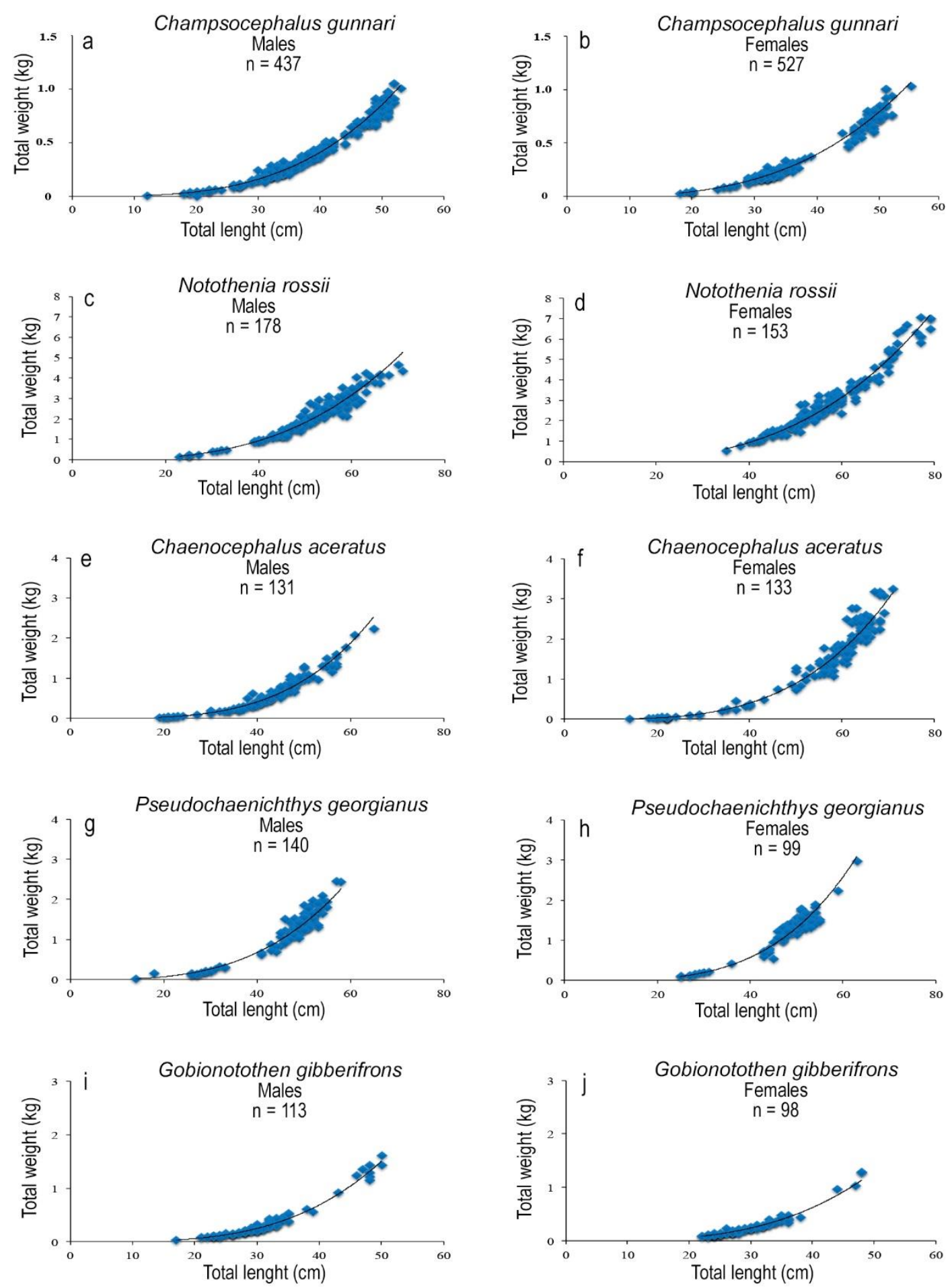

Figure 11. Total length-total weight relationship for the principal species during the cruise. a-b) Champsocephalus gunnari, c-d) Notothenia rossii, e-f) Chaenocephalus aceratus, g-h) Pseudochaenichthys georgianus, i-j) Gobionotothen gibberifrons.

The captured specimens showed total lengths (mean $=$ $52.16 \mathrm{~cm}$ ), exceeding the maximum sizes previously recorded in the same area by Kock et al. (2007) and Kock \& Jones (2012a).
Catches of $C$. gunnari made with bottom trawls were extremely low around Elephant Island and almost zero around the South Orkney Islands. The lengths of the captured specimens were centered in sizes between 
Table 6. The individual average weight $(\mathrm{kg})$ of fish caught with bottom trawling.

\begin{tabular}{|c|c|c|}
\hline Species & Code & Average weight $(\mathrm{kg})$ \\
\hline Notothenia rossii & NOR & 2,442 \\
\hline Champsocephalus gunnari & ANI & 0.344 \\
\hline Pseudochaenichthys georgianus & SGI & 1,241 \\
\hline Gobionotothen gibberifrons & NOG & 0.298 \\
\hline Chaenocephalus aceratus & SSI & 1,093 \\
\hline Lepidonotothen squamifrons & NOK & 0.382 \\
\hline Chionodraco rastrospinosus & $\mathrm{KIF}$ & 0.491 \\
\hline Gymnoscopelus nicholsi & GYN & 0.035 \\
\hline Notothenia coriiceps & NOC & 1,440 \\
\hline Dissostichus mawsoni & TOA & 13,141 \\
\hline Lepidonotothen larseni & NOL & 0.054 \\
\hline Bathyraja maccaini & BAM & 0.455 \\
\hline Trematomus eulepidotus & TRL & 0.174 \\
\hline Muraenolepis microps & MOY & 0.358 \\
\hline Bathyraja eatonii & BEA & 0.478 \\
\hline Trematomus hansoni & TRH & 0.655 \\
\hline Cryodraco antarcticus & FIC & 0.066 \\
\hline Ophthalmolycus amberensis & LYA & 0.410 \\
\hline Notothenia squamifrons & NOS & 0.142 \\
\hline Parachaenichthys charcoti & $\mathrm{PCH}$ & 0.109 \\
\hline Nototheniops nudifrons & NOD & 0.068 \\
\hline Anotopterus pharao & ANH & 0.600 \\
\hline Pogonophryne marmorata & PGM & 0.350 \\
\hline Pogonophryne spp. & POG & 0.405 \\
\hline Neopagetopsis ionah & JIC & 0.213 \\
\hline Pogonophryne scotti & SZT & 0.295 \\
\hline Racovitzia glacialis & RGG & 0.118 \\
\hline Bathydraco antarcticus & BDN & 0.180 \\
\hline Notothenia acuta & NOA & 0.155 \\
\hline Trematomus newnesi & TRW & 0.110 \\
\hline Paraliparis spp. & PVZ & 0.020 \\
\hline
\end{tabular}

28 and $40 \mathrm{~cm}$, similar to Kock et al. $(2002,2007)$ and Kock \& Jones (2012a), with a sex ratio in which females predominated slightly over males.

A remarkable aspect was the finding of a large number of small mackerel icefish juveniles, on the west side of the Elephant Island continental shelf (92-135 $\mathrm{m})$, which would indicate the presence of a nursery area for this species. Meanwhile, C. gunnari adults concentrated in deeper waters (Alegría \& Arana, 2016; Alegría et al., 2017). The specimens found in great abundance in this place, with a size of 5-13 cm TL, possibly correspond to the young of the one-year class (Frolkina, 1989).

All the cruises carried out in these areas have found the highest concentration of fishes north and northwestern of Elephant Island (e.g., Jones et al., 2001; Kock \& Jones, 2002, 2012a) and north, northwestern and northeastern of the South Orkney Islands (e.g., Arana et al., 2016). It should be noted that
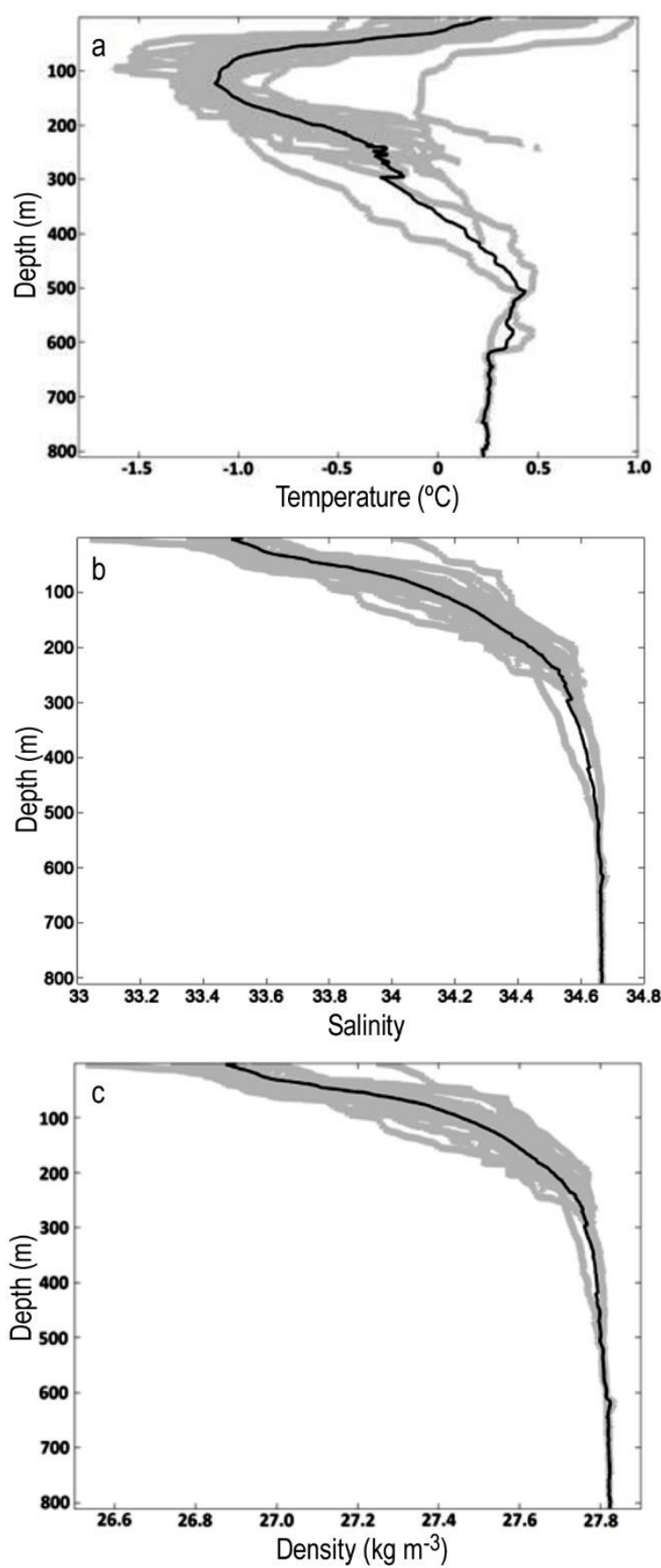

Figure 12. Temperature profiles a) temperature, b) salinity, c) density around the South Orkney Islands. The black line represents the average temperature of all the profiles.

the Antarctic krill Euphausia superba constitutes the main food of C. gunnari and N. rossii (e.g., Kock, 1991; Jones et al., 1999a, 2003) and that concentrations of krill can also found in these geographic regions.

The parameters obtained from the length-weight relationship were similar to those indicated by Kock \& Jones (2005, 2012a). 
This time, most individuals sampled were in the gonad stage of developing, or developed, with practically none in the mature or post-spawning state. $N$. rossii was the species that presented the most development in its gonads, which would be explained by the fact that the spawning period of this species is estimated to take place between May and June around Elephant Island, according to those same authors. On the other hand, Pseudochaenichthys georgianus would spawn in March, according to Gubsch (1982) or MayJune, according to Kock \& Jones (2012a). This situation was not reflected in the information collected during this survey. However, when comparing these results, with those obtained in the same 2016 period, a different result is achieved. According to Plaza et al. (2016), finding hydrated ovaries in species like these, which commonly spawn in autumn or winter, would be because they have a more extended period of reproduction or that interannual variations are produced associated with environmental factors that activate the spawning season.

Acoustic records provided potentially new information on the distribution of pelagic resources, such as krill and semi-pelagic finfish species such as mackerel icefish, as well as other finfish species. Strong evidence of $C$. gunnari aggregations were detected in the north and northwest sectors of both islands, similar to findings of Jones et al. (1999a, 2001), Jones \& Kock (2009), Kock \& Jones (2012a), Alegría \& Arana (2016), and Arana et al. (2016). In C. gunnari, shoals were detected acoustically around Elephant Island corresponding to areas with steep slopes, while in flat bottom areas, their presence was low or null. According to Alegría et al. (2017), these concentrations showed different forms of aggregation: some near the bottom, forming dense shoals above $10 \mathrm{~m}$ from the seafloor, while in other cases, shoals were raised at significant heights, with individuals dispersed in the water column. Similar to a previous study (Kasatkina \& Frolkina, 2003), the results obtained during this survey indicated a high correlation between mackerel icefish and krill concentrations, which can be expected given that krill represents the main prey-food of this species (e.g., Kock, 1991; Jones, 2000; Jones et al. 2003). On the other hand, the apparent low abundance of $G$. gibberifrons around Elephant Island confirmed a continuing declining trend for this species (Kock \& Jones, 2012b).

During this survey, a single large concentration of mackerel icefish was identified northwest of Elephant Island, coinciding with the region where dense concentrations had been reported in previous surveys (Jones et al., 2003; Arana et al., 2018). Across the rest of the study area, as well as the South Orkney Islands, this species was present in very low quantities, differing from previous investigations, where significant concentrations were found in several places around both islands. The reason for this difference cannot be explained with the available information. However, it could be related to the prevailing lunar phase when the survey was carried out (waning and new moon) when according to anecdotal reports from fishers, this species only concentrates during crescent and full moon phases.

It's worthwhile noting that this species is mainly demersal during daylight hours, and thus are difficult to detect by hydroacoustic means (Ona \& Mitson, 1996; SIMRAD, 2000; Simmonds \& MacLennan, 2006). Additionally, when using bottom trawl nets with a narrow vertical opening at the mouth, it is difficult or impossible to correlate the catches obtained from resources that are immediately above the height of the influence of the net.

In most cases, $C$. gunnari remains very close to the seafloor and is much better sampled by bottom trawls than semi-pelagic gear (Kock \& Jones, 2005; CCAMLR, 2006, 2011b). For this reason, mackerel icefish is currently surveyed using bottom trawling. Still, the resulting abundance estimates may be biased due to the semi-pelagic distribution, as has been described by Gherasimchook (1987), Shust (1998), Kasatkina \& Frolkina (2003), among others; or described as benthopelagic by Jones et al. (2003) and other authors. An acoustic estimate of the pelagic component of the population could indicate the magnitude of this bias (Fallon et al., 2016). For this reason, the identification of the correct concentration, their geographical and bathymetric distribution, and the simultaneous use of midwater trawling with bottom trawling combined with an acoustic survey, would contribute to better estimating the $C$. gunnari biomass in the Southern Ocean, especially when this species is dispersed in the water column.

On the other hand, it is well known that $C$. gunnari concentrates in certain places within its bathymetric range. In contrast, in others, its presence is almost null, a characteristic that has been observed in various investigations carried out in the Southern Ocean. This feature indicates the need to rethink methodologies required to estimate biomass for this species, particularly concerning patchy concentrations in relatively small geographic areas, and their absence in others.

Finally, it is important to determine the status of the population of $C$. gunnari and other demersal fish species in an area that has remained closed to fishing for almost three decades. To this end, efforts aimed at expanding both biological and sampling strategies for this species must be continued to determine the degree of its recovery reliably. 


\section{ACKNOWLEDGMENTS}

Special thanks are due to the national and foreign research team that participated in this investigation. The fishing master Mr. Mauricio Andrade, the first officer Mr. Héctor Martínez, and the entire crew of the FV Cabo de Hornos for their collaboration in the tasks developed during the realization of this project. Also, thanks to Deris S.A. for providing the ship to carry out the work at sea, and to Mr. Enrique Gutiérrez, general manager of this company, for his permanent support in materializing these tasks. The authors of this report also thank Dr. Alex Dornburg (North Carolina Museum of Natural Sciences, USA), Dr. Elyse Parker (Yale University, USA), Miss Loreto Ramírez (National Observer, Chile), and Mr. Francisco Gallardo (Pontificia Universidad Católica de Valparaíso, Chile) for their collaboration in the sampling and collection of information. Also, to Mr. Jairo Gutiérrez for the preliminary analysis of the oceanographic records.

\section{REFERENCES}

Alegría, N. \& Arana, P.M. 2016. Hydroacoustic survey around Elephant Island (Subarea 48.1) and South Orkney Islands (Subarea 48.2), austral summer 2016. CCAMLR, WG-FSA 16/21: 13 pp.

Alegría, N., Arana, P.M. \& Sepúlveda, A. 2017. Hydroacoustic survey around Elephant Island (Subarea 48.1) and South Orkney Islands (Subarea 48.2), austral summer 2016. 2017 IEEE/OES Acoustics in Underwater Geosciences Symposium (RIO Acoustics), $5 \mathrm{pp}$.

Arana, P.M., Plaza, G., Arata, J., Alegría, N. \& Viquerat, S. 2016. Finfish distribution and abundance in Subareas 48.1 and 48.2, years 2016-2018. CCAMLR, WG-SAM-16/19: 29 pp.

Arana, P.M., Jones, C.D. \& Alegría, N. 2018. Demersal finfish distribution, abundance, and their biological characteristics in Statistical Subareas 48.1 (northern area) and 48.2 (2018-2020) - cruise report. CCAMLR, SAM-18/25: 54 pp.

Barrera-Oro, E., Marschoff, E. \& Ainley, D. 2017. Changing status of three notothenioid fish at the South Shetland Islands (1983-2016) after impacts of the 1970-80s commercial fishery. Polar Biology, 40(10): 2047-2054. doi: 10.1007/s00300-017-2125-0.

Commission for the Conservation of Antarctic Marine Living Resources (CCAMLR). 1990a. Report of the Ninth Meeting of the Commission (Hobart, Australia, 22 October-2 November 1990). CCAMLR, Hobart, 48 pp.
Commission for the Conservation of Antarctic Marine Living Resources (CCAMLR). 1990b. Statistical Bulletin, Vol. 1. CCAMLR, Hobart, 61 pp.

Commission for the Conservation of Antarctic Marine Living Resources (CCAMLR). 2006. Report of the Second Meeting of the Subgroup on Acoustic Survey and Analysis Methods (23 and 24 March 2006). CCAMLR, Hobart, 23 pp.

Commission for the Conservation of Antarctic Marine Living Resources (CCAMLR). 2011a. Scientific Observer Manual (Observation guidelines and reference material). CCAMLR, Hobart, 65 pp.

Commission for the Conservation of Antarctic Marine Living Resources (CCAMLR). 2011b. Fishery report: Champsocephalus gunnari South Georgia (Subarea 48.3). Appendix E. CCAMLR, Hobart, 13 pp.

Commission for the Conservation of Antarctic Marine Living Resources (CCAMLR). 2013a. Report on bottom fisheries and vulnerable marine ecosystems. [http: www.ccamlr.org/node/78917]. Reviewed: September $15,2019$.

Commission for the Conservation of Antarctic Marine Living Resources (CCAMLR). 2013b. Fish identification guide for Observers in CCAMLR krill fisheries. CCAMLR, WG-EMM-13/07: $6 \mathrm{pp}$.

Constable, A.J., De la Mare, W.K., Agnew, D.J., Everson, I. \& Miller, D. 2000. Managing fisheries to conserve the Antarctic marine ecosystem: practical implementation of the Convention on the Conservation of Antarctic Marine Living Resources (CCAMLR). ICES Journal of Marine Science, 57: 778-791.

De la Mare, W.K. 1994. Estimating confidence intervals for fish stock abundance estimates from crawl surveys. CCAMLR Science, 1: 203-207.

Dongwon, L. 2015. Species identification illustrated guide of the Southern Ocean-CCAMLR convention area 48, 58, and 88. CCAMLR, WG-EMM-15/06: 80 pp.

Dixon, W. \& Massey, J. 1957. Introduction to statistical analysis. McGraw-Hill, New York.

Fabra, A. \& Gascón, V. 2008. The Convention on the Conservation of Antarctic Marine Living Resources (CCAMLR) and the ecosystem approach. International Journal of Marine and Coastal Law, 23(3): 567598.

Fallon, N., Fielding, S. \& Fernandes, P. 2016. Classification of Southern Ocean krill and icefish echoes using random forests. CCAMLR, WG-EMM-16/23: $26 \mathrm{pp}$.

Fisher, W. \& Hureau, J.C. (Eds.). 1985. FAO species identification sheets for fishery purposes. Southern Ocean (Fishing areas 48, 58, and 88) (CCAMLR Convention Area). FAO, Rome.

Frolkina, Z.A. 1989. Methods of age determination for mackerel icefish (Champsocephalus gunnari Lonnberg, 
1905) from the South Georgia Island shelf. CCAMLR, WG-FSA-89/19: 13 pp.

Gherasimchook, V.V. 1987. Brief report of the joint Soviet-Australian expedition of the USSR FRV Professor Mesuatsev to the Australian fishing zone around the territory of Heard and Mcdonald Islands, May-August, 1987. Selected Scientific Papers, 1991 (SCCAMLR-SSP/4). CCAMLR, Hobart, pp. 49-74.

Griffiths, H.J. 2010. Antarctic marine biodiversity - what do we know about the distribution of fife in the Southern Ocean? Plos One, 5(8). doi: 10.1371/journal. pone. 0011683

Gubsch, G. 1982. Zur Verbreitung und Biologie der Eisfische (Chaenichthyidae) im Atlantischen Sektor der Antarktis. Fischerei-Forschung, 20: 39-47.

Hempel, G. 2007. Antarctic marine biology-two centuries of research. Antarctic Science, 19(2): 195-203.

International Commission for the Exploration of the Sea (ICES). 2007. Collection of acoustic data from fishing vessels. ICES Cooperative Research Report, 287: 83 pp.

Iwami, T. 1995. Fishes incidentally caught by Japanese Antarctic krill commercial fishery to the north of the South Shetland Islands during the 1994/95 austral summer. CCAMLR, WG-EMM-95/56: 6 pp.

Iwami, T. \& Naganobu, M. 2007. A guide to the identification of fishes caught along with the Antarctic krill. CCAMLR, WG-EMM-07/32: 27 pp.

Jones, C.D. 2009. Standing stock, spatial distribution, and biological features of demersal finfish from the 2009 U.S. AMLR bottom trawl survey of the South Orkney Islands (Subarea 48.2). CCAMLR, WG-FSA-09/19: $24 \mathrm{pp}$.

Jones, C.D. 2000. Revised estimates of seabed areas within the $500 \mathrm{~m}$ isobath of the South Orkney Islands (Subarea 48.2) and consequences for standing stock biomass estimates of nine species of finfish. CCAMLR Science, 7: 197-206.

Jones, C.D. \& Kock, K.-H. 2009. Standing stock, spatial distribution and biological features of demersal finfish from the 2009 US AMLR bottom trawl survey of the South Orkney Islands (Subarea 48.2). CCAMLR, WGFSA-09/19: 23 pp.

Jones, C.D., Sexton, S.N. \& Cosgrove III, R.E. 1999. Surface areas of seabed within the $500 \mathrm{~m}$ isobath for regions within the South Shetland Islands (Subarea 48.1). CCAMLR Science, 6: 133-140.

Jones, C.D., Kock, K.-H., Ramm, D., Ashford, J., Wilhelms, S., Near, T., Gong, N. \& Flores, H. 2001. Results and standing stock biomass estimates of finfish from the 2001 U.S. AMLR bottom trawl survey of the South Shetland Islands (Subarea 48.1). CCAMLR, WG-FSA-01/33 Rev 1: 44 pp.
Jones, C.D., Kock, K.-H., Wilhelms, S., Popp, J., Ramm, D., Dietrich, K., Kappes, P. \& Lombard, D. 1999a. Bottom trawl survey of the South Orkney Islands In: Martin, J. (Ed.). AMLR 1998/99 Field season report. South Fisheries Science Center, Florida, pp. 137-154.

Jones, C.D., Kock, K.-H., Ashford, J., DeVries, A., Detrich, K., Hanchet, S., Near, T., Turk, T. \& Wilhelms, S. 2003. Standing stock, biology, diet and spatial distribution of demersal finfish from the 2003 US AMLR bottom trawl survey of the South Shetland Islands (Subarea 48.1). CCAMLR, WG-FSA-03/38: $31 \mathrm{pp}$.

Kasatkina, S.M. \& Frolkina, Zn. 2003. A investigations of demersal mackerel icefish (C. gunnari) spatial distribution in relation to improvements in stock estimates by trawl-acoustic survey. ICES CM 2003/Q:05: 22 pp.

Kock, K.-H. 1991. The state of exploitation fish stocks in the Southern Ocean - a review. Archiv für Fischereiwissenschaft, 41(1): 1-66.

Kock, K.-H. \& Jones, C.D. 2005. Fish stocks in the Southern Scotia Arc Region - a review and prospects for future research. Review in Fisheries Science, 13: 75-108.

Kock, K.-H. \& Jones, C.D. 2012a. The composition, abundance and reproductive characteristics of demersal fish fauna in the Elephant Island-South Shetland Islands region and at the tip of the Antarctic Peninsula (CCAMLR Subarea 48.1) in March-early April 2012. CCAMLR, WG-FSA-12/10: 43 pp.

Kock, K.-H. \& Jones, C.D. 2012b. The recent decline in recruitment of Gobionotothen gibberifrons in the South Shetland Islands (CCAMLR Subarea 48.1). CCAMLR, WG-FSA-12/20: 13 pp.

Kock, K.-H. \& Kellermann, A. 1991. Reproduction in Antarctic notothenioid fish - a review. Antarctic Science, 3(2): 125-150.

Kock, K.-H., Appel, J., Busch, M., Klimpel, S., Holst, M., Pietschok, D., Pshenichnov, L.V., Riehl, R. \& Schöling, S. 2007. Composition and standing stock estimates of finfish from the 'Polarstern' bottom trawl survey around Elephant Island and the South Shetland Islands (Subarea 48.1), 19 December 2006 - 3 January 2007. CCAMLR, WG-FSA-07/22: 32 pp.

Kock, K-H., Jones, C.D., Appel, J., Bertouch, G.V., La Mesa, D.F., Pshenichnov, L., Riehl, R., Romeo, T., Schöling, S. \& Zane, L. 2002. Standing stock estimates of finfish biomass from the 2002 'Polarstern' bottom trawl survey around Elephant Island and the South Shetland Island with some notes on the composition of catches taken north of Joinville Island - D'Urville Island. CCAMLR, WG-FSA-02/24: 42 pp. 
MacLennan, D.N., Fernandes, P.G. \& Dalen, J. 2002. A consistent approach to definitions and symbols in fisheries acoustics. ICES Journal of Marine Science, 59: 365-369.

Marschoff, E.R., Barrera-Oro, E.R., Alescio, N.S. \& Ainley, D.G. 2012. Slow recovery of previously depleted demersal fish at the South Shetland Islands, 1983-2010. Fishery Research, 125-126: 206-213.

Murphy, R.C. 2014. The oceanic life of the Antarctic. In: Detrich, H.W. (Ed.). Antarctica: life on ice. Scientific American, Springer Nature, New York, pp. 319-332.

Nicol, S. \& Endo, Y. 1997. Krill fisheries of the world. FAO Fishery Technical Paper, 367: 100 pp.

Ona, E. \& Mitson, R.B. 1996. Acoustic sampling and signal processing near the seabed: the dead zone revisited. ICES Journal of Marine Science, 53: 677690.

Pennington, M. 1996. Estimating the mean and variance from highly skewed marine data. Fishery Bulletin, 94: 498-505.

Received: 29 November 2019; Accepted: 6 March 2020
Plaza, G., Arana, P.M., Becker, F., Zavatteri, A. \& Castillo, V.H. 2016. Spawning pattern and type of fecundity in notothenioid collected around the Elephant and South Orkney Islands. CCAMLR, WGFSA 16/22: 14 pp.

Reid, D.G., Fernandes, P.G., Bethke, E., Couperus, A., Goetze, E., Hakansson, N. et al. 1998. On visual scrutiny of echograms for acoustic stock estimation. ICES, CM 1998/B: 1.

Shust, K.V. 1998. Fishes and fish resources of the Antarctic. VNIRO, Moscow.

Simmonds, J. \& MacLennan, D. 2006. Fisheries acoustics: theory and practice. Blackwell, Oxford.

SIMRAD. 2000. Instruction manual. SIMRAD EK-60 Scientific Echo Sounder, 180 pp.

Tin, T., Fleming, Z.L., Hughes, K.A., Ainley, D.G., Convey, P., Moreno, C.A., Pfeiffer, S., Scott, J. \& Snape, I. 2009. Impacts of local human activities on the Antarctic environment. Antarctic Science, 21: 333. 